\title{
A petrological experiment on Emeishan basalt: Implications for the formation of syenite from the Baima igneous complex
}

\author{
Wen-Yu Hsia ${ }^{1}$, J. Gregory Shellnutt ${ }^{1, *}$, Teh-Ching Liu ${ }^{1}$, and Yoshiyuki Iizuka ${ }^{2}$ \\ ${ }^{1}$ National Taiwan Normal University, Department of Earth Sciences, Taipei City, Taiwan \\ ${ }^{2}$ Institute of Earth Sciences, Academia Sinica, Taipei City, Taiwan
}

\section{Article history: \\ Received 15 September 2020 \\ Revised 31 December 2020 \\ Accepted 30 January 2021}

Keywords:

Emeishan large igneous province, Baima igneous complex, A-type syenite, Layered gabbroic intrusion, Fe-Ti-oxide deposit

\section{Citation:}

Hsia, W.-Y., J. G. Shellnutt, T.-C. Liu, and Y. Iizuka, 2021: A petrological experiment on Emeishan basalt: Implications for the formation of syenite from the Baima igneous complex. Terr. Atmos. Ocean. Sci., 32, 319-338, doi: $10.3319 /$ TAO.2021.01.30.01

\begin{abstract}
The Baima igneous complex (BIC) consists of a cumulate layered gabbroic unit, an Fe-Ti oxide ore zone, and an isotropic quartz syenite. The formation of the BIC is attributed to a variety of petrological processes including: silicate immiscibility, fractional crystallization, and fluxing of $f \mathrm{O}_{2}$ by either internal or external factors. This study attempts to determine if a parental magma similar to high-Ti Emeishan basalt can produce the syenitic rocks of the BIC. The experimental results at atmospheric pressure show that the liquidus temperature and solidus temperature of the basaltic melt are estimated to be 1303 and $1120^{\circ} \mathrm{C}$. The crystallization sequence is: titanomagnetite, clinopyroxene $\left(\mathrm{Wo}_{43-47} \mathrm{En}_{32-45} \mathrm{Fs}_{11-23}\right)$, and plagioclase $\left(\mathrm{An}_{65-31}\right)$. The residual liquid composition, represented by quenched glass, evolves from lower $\mathrm{SiO}_{2}$ ( $\sim 45 \mathrm{wt} \%$ ) values to higher values ( $\sim 60 \mathrm{wt} \%)$ with corresponding decreases in $\mathrm{Ti}, \mathrm{Fe}$, $\mathrm{Mg}, \mathrm{Ca}$ and increases of $\mathrm{Na}$ and $\mathrm{K}$. The results show that a starting composition of high-Ti basalt from the Emeishan large igneous province can produce evolved silicic liquids that resemble the compositions of microgranular enclaves from the Baima syenitic unit.
\end{abstract}

\section{INTRODUCTION}

The current understanding of magma chamber processes is derived from observations of layered mafic-ultramafic intrusions preserved in the geological record and physical observations deduced from geophysical surveys at volcanic centers (Wager and Brown 1968; Iyer 1984; Cawthorn 1996; Murru et al. 1999; Charlier et al. 2015; Mondal and Griffin 2017). Many layered intrusions are of significant economic importance as they host world class deposits of precious (PGE, $\mathrm{Au}, \mathrm{Ag}$ ) and base $(\mathrm{Fe}, \mathrm{Ni}, \mathrm{Zn})$ metals. Therefore, constraining the processes that enrich layered intrusions in precious and/or base metals is of primary importance for mineral exploration (Lee 1996). Specifically, the formation of magmatic Fe-Ti-V oxide deposits is not well understood although many occur in the upper, more differentiated units of layered intrusions whereas the lower units

\footnotetext{
* Corresponding author

E-mail:jgshelln@ntnu.edu.tw
}

commonly have Cr- and PGE-rich horizons (e.g., Bushveld Complex, Stillwater Complex).

Fractional crystallization, magma mingling, silicate liquid immiscibility, separate magma systems, and oxygen fugacity $\left(f \mathrm{O}_{2}\right)$ fluxing are suggested as possible processes which induce metal enrichment but there remains a large degree of uncertainty. It appears that there is no general model that can be applied to all deposits associated with layered intrusions but rather there are specific conditions unique to each deposit that may be important to their formation (Philpotts 1967; Cawthorn 1996; Lee 1996; Duchesne 1999; Van Tongeren and Mathez 2012; Charlier et al. 2015). Furthermore, many layered intrusions are associated with silicic plutons that are similar to A-type (ferroan) granitoids (Bonin 2007). The spatial and temporal association of silicic intrusions with layered ultramafic-mafic intrusions suggests they may be petrogenetically related and that the formation of $\mathrm{Fe}$-Ti oxide deposits is a consequence of their cogenesis 
(Shellnutt et al. 2009, 2011; Shellnutt and Jahn 2010; Zhong et al. 2011).

The middle-Late Permian ( 260 Ma) Emeishan large igneous province (ELIP) of southwestern China is located along the western margin of the Late Archean to Early Proterozoic Yangtze Block. The ELIP covers an area of $\sim 0.5 \times$ $10^{6} \mathrm{~km}^{2}$ and consists principally of continental flood basalts but there are a number of mafic-ultramafic intrusions, some of which host giant $\mathrm{Fe}-\mathrm{Ti}-\mathrm{V}$ oxide deposits and/or Ni-Cu(PGE) sulphide deposits (Ali et al. 2005; Zhong et al. 2005; Song et al. 2006, 2013; Wang et al. 2007; Zhou et al. 2008; Pang et al. 2010; Shellnutt 2014; Pang and Shellnutt 2017). The oxide-bearing layered ultramafic-mafic complexes are concentrated within the west-central part of the ELIP known as the Panxi region (Panzhihua-Xi Chang). The layered complexes can be divided into two main groups: (1) ultramafic-mafic and (2) mafic. The ultramafic-mafic intrusions typically consist of a lower olivine- and pyroxenerich peridotite unit which grades into a plagioclase-bearing upper gabbroic unit whereas the mafic layered intrusions consist of gabbro with varying proportions of olivine, clinopyroxene, plagioclase, and titanomagnetite across all layers (Zhong et al. 2002; Zhou et al. 2005; Wang et al. 2007; Pang et al. 2010; Shellnutt et al. 2011, 2015; Pêcher et al. 2013; Song et al. 2013; Bai et al. 2014; She et al. 2014; Pang and Shellnutt 2017). The primary difference between the two groups is the type and style of mineralization. The mafic-ultramafic intrusions have PGE-rich horizons in their lower parts and Fe-Ti-oxide deposits in their middle to upper layers (e.g., Hongge). In contrast the mafic intrusions strictly have Fe-Ti oxide deposits (e.g., Panzhihua, Taihe, Baima) in their lower layers (Zhou et al. 2008; Pang et al. 2010). Another difference between the two types of layered intrusions is that the mafic intrusions are spatially and temporally associated with peralkaline A-type granitoids whereas the ultramafic-mafic intrusions are not. The petrogenetic relationship between the mafic intrusions and the peralkaline granitic intrusions is a contentious issue and is focused on whether or not the spatially associated mafic and silicic rocks are members of the same complex (Shellnutt et al. 2011; Zhong et al. 2011; Zhang et al. 2012). Additionally the formation of the $\mathrm{Fe}$-Ti oxide deposits within the mafic intrusions are considered to be derived by a number of processes such as: silicate liquid immiscibility, fractional crystallization or $f \mathrm{O}_{2}$ fluxing by carbonate country rock assimilation from either a mafic or ultramafic parental magma (Zhou et al. 2005, 2013; Ganino et al. 2008; Pang et al. 2008a, b, 2009; Zhang et al. 2009, 2012; Shellnutt et al. 2011, 2015; Zhong et al. 2011; Song et al. 2013; Liu et al. 2014a, b, 2016; She et al. 2014; Bai et al. 2016; Chen et al. 2017; Tang et al. 2017; Xing et al. 2017).

In this paper we present the results of low pressure (atmospheric), anhydrous equilibrium crystallization ex- periments on a 'high-Ti' Emeishan basalt composition in order to determine if the syenitic unit of the Baima igneous complex can be derived from a mafic parental magma. Moreover, the results of this study have implications for the formation of orthomagmatic Fe-Ti oxide deposits of the Panxi region.

\section{PETROLOGY OF THE BAIMA IGNEOUS COMPLEX}

The Baima igneous complex (BIC) is located in the central part of the Panxi region, $\sim 100 \mathrm{~km}$ northeast of Panzhihua city, and consists of a gabbroic unit, a syenitic unit and massive oxide ore deposit (Fig. 1). The layered gabbroic unit lies to the east of the syenitic unit and dips $\sim 23$ to $27^{\circ}$ to the west and is estimated to contain $1150 \mathrm{Mt}$ of Fe, 44.8 Mt of Ti, and 2.85 Mt of V (Zhong et al. 2005). The two units appear to cover an area of similar size, but their respective volumes are unknown. Zircon U-Pb SHRIMP ages of $258 \pm 4 \mathrm{Ma}$ and $259 \pm 5 \mathrm{Ma}$ of the syenitic unit are within error of the $261 \pm 2$ Ma of the gabbroic unit (Shellnutt et al. 2009). It is thought that the layered intrusive rocks and the syenites are comagmatic and cogenetic (Yang et al. 1997; Shellnutt et al. 2009; Zhong et al. 2011; Liu et al. 2014a).

The gabbroic unit can be divided into four lithologic zones from the bottom to the top: (1) a lower cumulate zone; (2) an oxide ore zone; (3) an olivine gabbro zone; and (4) an upper gabbro zone (Chen 1990) (Fig. 2). The rocks from the four zones consist of coarse grained cumulus olivine, plagioclase, clinopyroxene, and interstitial Fe-Ti oxide minerals with minor amounts of sulphide minerals, spinel (pleonaste), and apatite (Chen 1990; Shellnutt and Pang 2012; Liu et al. 2014a; Chen et al. 2014). The upper zone tends to have less olivine and more apatite than the lower cumulate zone and the olivine gabbro zone. The ore deposits are hosted within the lower portions of the layered cumulate gabbro (Chen 1990; Shellnutt et al. 2009).

The syenite is coarse grained, granular and consists of perthitic alkali feldspar, sodic amphibole, quartz, aegirine and accessory amounts $(\leq 5 \mathrm{vol} \%)$ of apatite, titanite, zircon, plagioclase, fluorite, biotite, ilmenite, magnetite, and pyrite (Shellnutt and lizuka 2011). The syenitic unit is structurally above the gabbroic unit and contains ellipsoidal microgranular enclaves varying in size from a few centimeters to 10s of centimeters in length (Shellnutt et al. 2010). There are a few small lenticular zones of finer grained textures which are more siliceous in composition. All units of the BIC were intruded by alkaline mafic dykes $(257.6 \pm 0.5 \mathrm{Ma}$ to $259.5 \pm 0.8 \mathrm{Ma}$ ) whereas the petrogenetically unrelated Woshui syenite $(259.6 \pm 0.5 \mathrm{Ma})$ and Huangcao syenite $(258.9 \pm 0.7 \mathrm{Ma})$ intruded the margins of the BIC (Shellnutt and Zhou 2007, 2008; Shellnutt et al. 2008, 2012; Shellnutt and Iizuka 2011). 


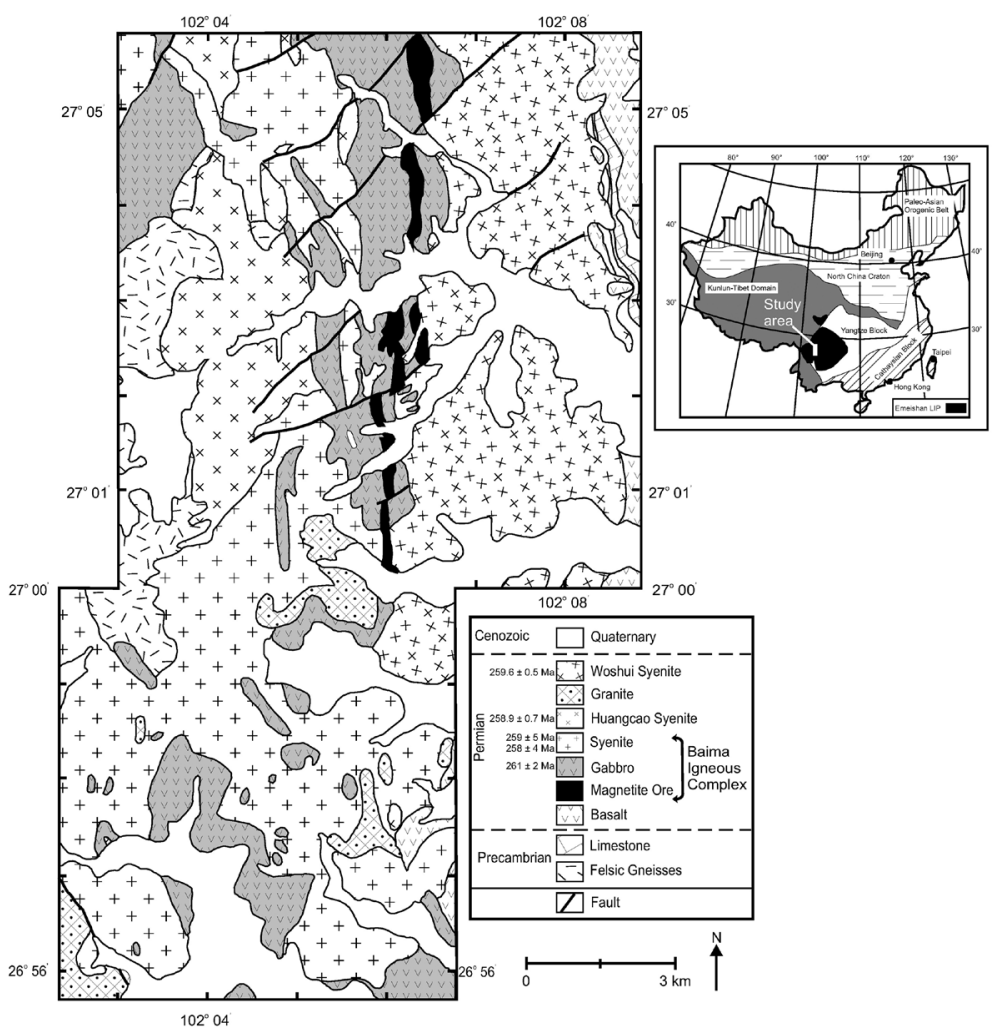

Fig. 1. Simplified geological map showing the distributions of the major units of the BIC (modified from Wang et al. 1994 and Xiong et al. 1996). Zircon U-Pb age dates from Shellnutt et al. (2009, 2012).

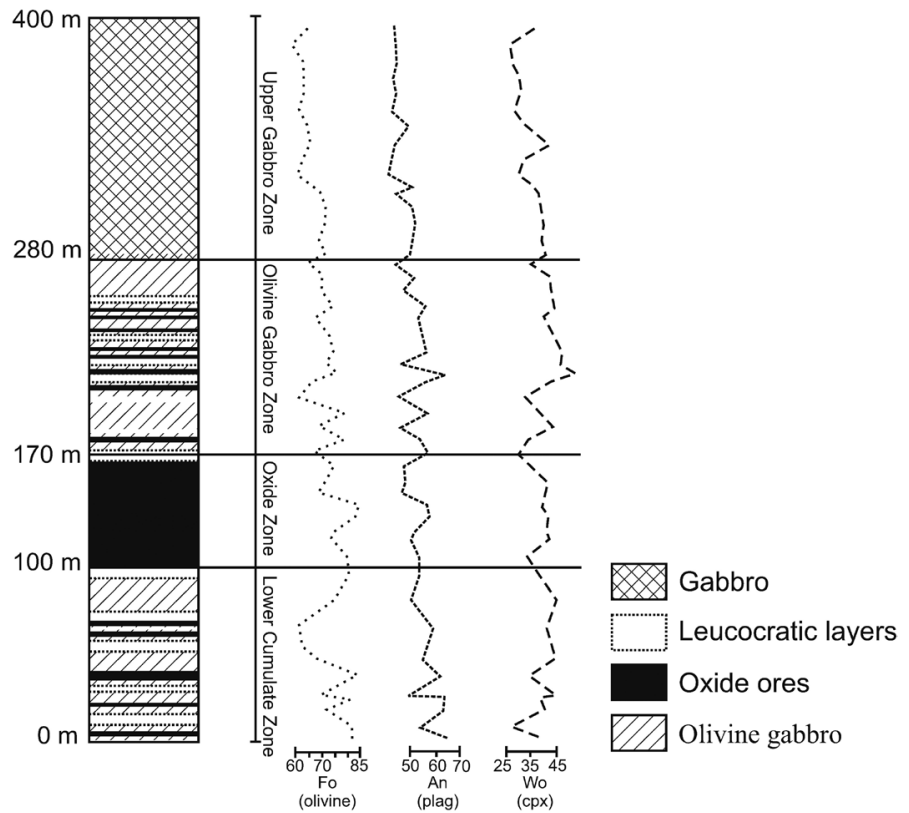

Fig. 2. The stratigraphic column of the layered gabbro of the BIC showing the different facies based on Chen (1990). Mineral chemical variations after Chen (1990) are shown for reference. $\mathrm{Fo}=$ forsterite value, $\mathrm{An}=$ anorthite value, $\mathrm{Wo}=$ wollastonite value. 


\section{STARTING COMPOSITION AND EXPERIMENTAL SET-UP}

\subsection{Starting Composition}

Previous studies have suggested that the parental magma composition of the BIC was similar to the high-Ti Emeishan basalt (Shellnutt et al. 2009), specifically sample EM-81 reported by Xu et al. (2001). In this study, we selected a known composition of Emeishan high-Ti basalt from the Baima area as the parental magma of the BIC syenite (Table 1). Sample GS04-026 was collected from a mafic dyke with chilled margins that intruded the syenitic portion of the BIC and is reported by Shellnutt et al. (2008). The bulk composition of GS04-026 is similar to EM-81 but there are some minor differences with respect to the $\mathrm{Al}_{2} \mathrm{O}_{3}, \mathrm{Fe}_{2} \mathrm{O}_{3}$, and $\mathrm{Na}_{2} \mathrm{O}$ contents (Table 1). Given the low $\mathrm{MgO}(<8 \mathrm{wt} \%)$ and $\mathrm{CaO}(<12.0 \mathrm{wt} \%)$ contents of GS04-026, it is probably not representative of a primary melt but likely that it experienced crystal fractionation (e.g., olivine, \pm clinopyroxene \pm plagioclase) prior to emplacement.

\subsection{Experimental Conditions}

The rock powder was encased in closed platinum envelopes and was suspended in a 1-atm vertical-quenching furnace. The samples were melted at the desired temperature. All temperatures were measured using an R-type thermocouple ( $\mathrm{Pt}-\mathrm{Pt}_{87} \mathrm{Rh}_{13}$ thermocouple) and were corrected to the International Practical Temperature Scale of 1968 based on the calibration with the melting point of synthetic diopside $\left(\mathrm{CaMgSi}_{2} \mathrm{O}_{6}\right)$. The precision of the thermocouple is $\pm 1^{\circ} \mathrm{C}$. The experimental duration in this study ranged from 6 to 47.5 hours at temperatures from 1305 to $1125^{\circ} \mathrm{C}$. At the end of each run, the products were quenched in water. The complete results of the low pressure experiments can be found in Table $\mathrm{S} 1$ of the online supplementary files. The total $\mathrm{FeO}$ of the starting material is $14.83 \mathrm{wt} \%$. The total $\mathrm{FeO}$ of the glass melted at $1310^{\circ} \mathrm{C}$ and atmospheric pressure for six hours is $14.67 \mathrm{wt} \%$. The difference between them is $\sim 1 \%$ and therefore, the iron loss to the Pt envelope at atmospheric pressure was negligible.

\section{ANALYTICAL METHODS}

\subsection{Electron Probe Micro Analyzer}

After quenching, the experimental charges were mounted in epoxy and polished to make a section for mineral analysis. The mineralogical investigation was carried out by an electron probe micro analyzer (JEOL EPMA JXA-8900R) equipped with four wave-length dispersive spectrometers (WDS) at the Institute of Earth Sciences, Academia Sinica in Taipei. Secondary- and back-scattered electron images were taken of each sample and used to select specific minerals for analysis. A $2 \mu \mathrm{m}$ defocused beam
Table 1. Composition of starting material, EM-81 and average high-Ti Emeishan basalt.

\begin{tabular}{|c|c|c|c|}
\hline Element & GS04-026 & EM-81 & High- $\mathbf{T i}_{\text {avg }}$ \\
\hline $\mathrm{SiO}_{2}(\mathrm{wt} \%)$ & 45.01 & 44.51 & 47.52 \\
\hline $\mathrm{TiO}_{2}$ & 3.97 & 3.47 & 3.44 \\
\hline $\mathrm{Al}_{2} \mathrm{O}_{3}$ & 12.42 & 13.75 & 13.33 \\
\hline $\mathrm{Fe}_{2} \mathrm{O}_{3} \mathrm{t}$ & 16.48 & 16.37 & 14.20 \\
\hline $\mathrm{MnO}$ & 0.24 & 0.22 & 0.20 \\
\hline $\mathrm{MgO}$ & 5.89 & 6.93 & 5.61 \\
\hline $\mathrm{CaO}$ & 10.16 & 10.15 & 8.96 \\
\hline $\mathrm{Na}_{2} \mathrm{O}$ & 3.23 & 2.40 & 2.67 \\
\hline $\mathrm{K}_{2} \mathrm{O}$ & 1.34 & 1.08 & 1.17 \\
\hline $\mathrm{P}_{2} \mathrm{O}_{5}$ & 0.30 & 0.35 & 0.43 \\
\hline Total & 99.04 & 99.23 & 97.06 \\
\hline $\mathrm{Sc}(\mathrm{ppm})$ & 33 & & \\
\hline V & 893 & 438 & \\
\hline $\mathrm{Cr}$ & 26 & 98 & \\
\hline Co & 57 & 52 & \\
\hline $\mathrm{Ni}$ & 61 & 86 & \\
\hline $\mathrm{Cu}$ & 333 & 209 & \\
\hline $\mathrm{Zn}$ & 158 & 121 & \\
\hline $\mathrm{Ga}$ & 23 & 26 & \\
\hline $\mathrm{Rb}$ & 62 & 35 & \\
\hline $\mathrm{Sr}$ & 401 & 780 & \\
\hline Y & 26 & 35 & \\
\hline $\mathrm{Zr}$ & 165 & 227 & \\
\hline $\mathrm{Nb}$ & 21 & 31 & \\
\hline Cs & 0.7 & & \\
\hline $\mathrm{Ba}$ & 310 & 590 & \\
\hline $\mathrm{La}$ & 24.5 & 29.6 & \\
\hline $\mathrm{Ce}$ & 54.2 & 63.8 & \\
\hline $\operatorname{Pr}$ & 7.2 & & \\
\hline $\mathrm{Nd}$ & 30.5 & 35.9 & \\
\hline $\mathrm{Sm}$ & 6.8 & 8.5 & \\
\hline $\mathrm{Eu}$ & 2.2 & 2.8 & \\
\hline $\mathrm{Gd}$ & 6.0 & & \\
\hline $\mathrm{Tb}$ & 1.0 & 1.1 & \\
\hline Dy & 5.5 & & \\
\hline Ho & 1.0 & & \\
\hline $\mathrm{Er}$ & 2.8 & & \\
\hline $\mathrm{Tm}$ & 0.4 & & \\
\hline $\mathrm{Yb}$ & 2.3 & 2.3 & \\
\hline $\mathrm{Lu}$ & 0.3 & 0.3 & \\
\hline $\mathrm{Hf}$ & 4.6 & 5.8 & \\
\hline $\mathrm{Ta}$ & 1.5 & 1.7 & \\
\hline Th & 3.2 & 0.7 & \\
\hline $\mathrm{U}$ & 0.8 & 0.3 & \\
\hline
\end{tabular}


or a focused beam were operated for quantitative analysis at an acceleration voltage of $15 \mathrm{kV}$ and beam current of $12 \mathrm{nA}$. The measured X-ray intensities were corrected by ZAF method using the standard calibration of synthetic chemical-known standard minerals with various diffracting crystals that included: diopside or wollastonite for $\mathrm{Si}$ with TAP crystal, rutile for Ti with PET crystal, corundum for Al (TAP), chromium oxide for Cr (PET), fayalite or hematite for Fe with LiF crystal, tephroite for Mn (PET), periclase for Mg (TAP), wollastonite for Ca (PET), albite for $\mathrm{Na}$ (TAP), and adularia for K (PET). Peak counting for each element and both upper and lower baseline $\mathrm{X}$-rays are counted for 10 and $5 \mathrm{~s}$, respectively. Standard reference materials yielded relative standard deviations of $<1 \%$ for $\mathrm{Si}$, $\mathrm{Na}$ and $\mathrm{K}$, and $<0.5 \%$ for other elements.

\subsection{Laser Ablation (LA) Inductively Coupled Mass Spectrometry (ICP-MS)}

The trace elements were measured by inductively coupled plasma-mass spectrometry (ICP-MS) using an Agilent 7500s quadrupole spectrometer at the Department of Geosciences, National Taiwan University. The laser ablation was performed with a helium carrier gas and spot size of ablation was $30 \mu \mathrm{m}$, with laser repetition rate and laser energy density being $4 \mathrm{~Hz}$ and of $10 \mathrm{~J} \mathrm{~cm}^{-2}$, respectively. The USGS glass (NIST 610) was used as the external standard and BCR-2 was also used as secondary standard for verification of analytical results. Calcium (determined by EPMA) was used as the internal normalization standard for the glass. All concentrations were calculated using GLITTER 4.0 (GEMOC) software. The measured results of NIST 610 and BCR-2 are in supplementary Table S2 together with literature reference values. The precision of $~ 30$ trace elements measured is generally better than $10 \%$.

\section{RESULTS}

The temperature range for the low pressure experiments was 1310 to $1125^{\circ} \mathrm{C}$ with a liquidus temperature of $\sim 1303^{\circ} \mathrm{C}$ whereas the solidus temperature is estimated to be $\sim 1120^{\circ} \mathrm{C}$. The complete crystallization sequences for each experiment are shown in Table 2 but the overall crystallization sequence is iron-titanium (Ti-rich magnetite) oxide at $1303^{\circ} \mathrm{C}$, clinopyroxene at $1184^{\circ} \mathrm{C}$, and plagioclase at $1162^{\circ} \mathrm{C}$ (Fig. 3).

The average compositions of the iron-titanium oxides for each experiment are listed in Table 3. The bulk FeOt content of the oxides, at high temperature, ranges from $\sim 75$ to $\sim 65 \mathrm{wt} \%$ for all compositions with calculated $\mathrm{FeO}$ content from 31.7 to $36.2 \mathrm{wt} \%, \mathrm{Fe}_{2} \mathrm{O}_{3}$ from 36.1 to $46.6 \mathrm{wt} \%$, and $\mathrm{TiO}_{2}$ from 9.8 to $15.8 \mathrm{wt} \%$. The lowest temperature run produced both Ti-rich magnetite and ilmenite but the former was more abundant than the latter (Fig. 3).

The average clinopyroxene compositions are listed in Table 4. The wollastonite (Wo) component of the pyroxenes ranges from 49.4 to $44.3 \mathrm{~mol}$. \%; the enstatite (En) component ranges from 45.2 to $32.9 \mathrm{~mol}$. \%; and the ferrosilite (Fs) component ranges from 20.7 to $8.6 \mathrm{~mol}$. \%. The clinopyroxene classifies as diopside-augite (Fig. 4). The $\mathrm{TiO}_{2}$

Table 2. Experimental conditions and crystallization history.

\begin{tabular}{ccccc}
\hline Run & Pressure & Temp $\left({ }^{\circ} \mathbf{C}\right)$ & Time $(\mathbf{h}: \mathbf{m})$ & Phases \\
\hline BM-023 & 1 atm & 1310 & $6: 00$ & $\mathrm{gl}$ \\
BM-028 & 1 atm & 1305 & $6: 10$ & $\mathrm{gl}$ \\
BM-005 & 1 atm & 1300 & $6: 10$ & $\mathrm{gl}+\mathrm{mt}$ \\
BM-018 & 1 atm & 1294 & $22: 00$ & $\mathrm{gl}+\mathrm{mt}$ \\
BM-015 & 1 atm & 1286 & $21: 00$ & $\mathrm{gl}+\mathrm{mt}$ \\
BM-014 & 1 atm & 1275 & $26: 50$ & $\mathrm{gl}+\mathrm{mt}$ \\
BM-004 & 1 atm & 1250 & $19: 30$ & $\mathrm{gl}+\mathrm{mt}$ \\
BM-003 & 1 atm & 1198 & $47: 30$ & $\mathrm{gl}+\mathrm{mt}$ \\
BM-024 & 1 atm & 1187 & $17: 40$ & $\mathrm{gl}+\mathrm{mt}$ \\
BM-026 & 1 atm & 1180 & $19: 00$ & $\mathrm{gl}+\mathrm{mt}+\mathrm{px}$ \\
BM-008 & 1 atm & 1173 & $20: 34$ & $\mathrm{gl}+\mathrm{mt}+\mathrm{px}$ \\
BM-022 & 1 atm & 1165 & $38: 20$ & $\mathrm{gl}+\mathrm{mt}+\mathrm{px}$ \\
BM-027 & 1 atm & 1159 & $21: 00$ & $\mathrm{gl}+\mathrm{mt}+\mathrm{px}+\mathrm{pl}$ \\
BM-001 & 1 atm & 1151 & $17: 20$ & $\mathrm{gl}+\mathrm{mt}+\mathrm{px}+\mathrm{pl}$ \\
BM-007 & $1 \mathrm{~atm}$ & 1125 & $19: 50$ & $\mathrm{gl}+\mathrm{mt}+\mathrm{il}+\mathrm{px}+\mathrm{pl}$ \\
\hline
\end{tabular}

Note: $h: m=$ hours:minutes; $g l=$ glass, $m t=$ magnetite, $p x=$ clinopyroxene, $p l=p l a$ gioclase, il = ilmenite 
(a)

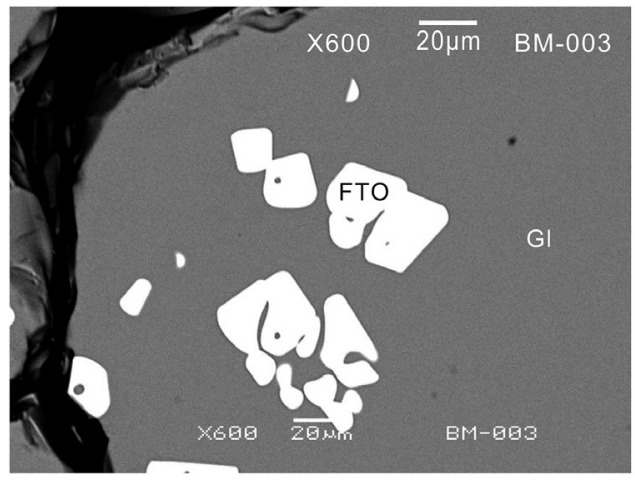

(b)

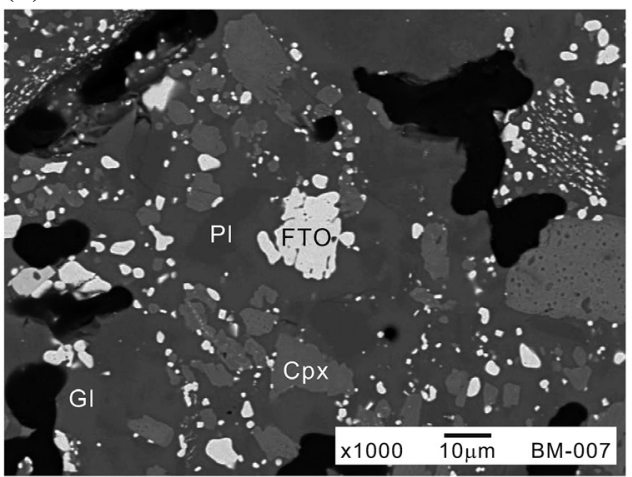

Fig. 3. Scanning electron microscopy images. (a) Crystallization of magnetite structured spinel at $1198^{\circ} \mathrm{C}$. (b) Crystallization of diopside-augite and plagioclase at $1125^{\circ} \mathrm{C}$.

Table 3. Average composition of the magnetite and ilmenite.

\begin{tabular}{|c|c|c|c|c|c|c|c|c|c|c|}
\hline Sample & BM-005 & BM-026 & s.d. & BM-027 & s.d. & BM-007 & s.d. & BM-007 & s.d. & Baima* \\
\hline Temp. $\left({ }^{\circ} \mathrm{C}\right)$ & 1300 & 1180 & (8) & 1159 & (9) & 1125 & (5) & 1125 & (3) & $\mathrm{PO}$ \\
\hline $\mathrm{SiO}_{2}(\mathrm{wt} \%)$ & 0.01 & 0.03 & 0.02 & 0.09 & 0.09 & 0.00 & & & & \\
\hline $\mathrm{TiO}_{2}$ & 9.79 & 12.72 & 0.25 & 13.76 & 0.44 & 14.51 & 1.87 & 44.62 & 1.76 & 13.13 \\
\hline $\mathrm{Al}_{2} \mathrm{O}_{3}$ & 2.12 & 1.90 & 0.05 & 1.71 & 0.09 & 1.80 & 0.43 & 1.09 & 0.67 & 4.45 \\
\hline $\mathrm{Cr}_{2} \mathrm{O}_{3}$ & 0.06 & & & & & & & & & \\
\hline $\mathrm{FeOT}$ & 75.91 & 71.54 & 0.60 & 70.06 & 0.58 & 68.55 & 1.68 & 40.27 & 2.13 & \\
\hline $\mathrm{NiO}$ & 0.08 & 0.03 & 0.03 & 0.03 & 0.02 & 0.05 & 0.06 & 0.03 & 0.01 & \\
\hline $\mathrm{MnO}$ & 0.11 & 0.20 & 0.04 & 0.25 & 0.06 & 0.35 & 0.07 & 0.18 & 0.10 & 0.49 \\
\hline $\mathrm{MgO}$ & 3.32 & 5.32 & 0.11 & 5.90 & 0.25 & 6.04 & 0.28 & 5.97 & 1.12 & 1.89 \\
\hline Total & 91.39 & 91.73 & & 91.82 & & 91.30 & & 92.16 & & \\
\hline $\mathrm{Fe}_{2} \mathrm{O}_{3}$ & 46.57 & 42.20 & 0.59 & 40.52 & 0.64 & 38.80 & 2.64 & 12.35 & 1.88 & 39.91 \\
\hline $\mathrm{FeO}$ & 34.00 & 33.56 & 0.27 & 33.60 & 0.59 & 33.64 & 1.90 & 29.16 & 1.03 & 41.18 \\
\hline Total & 96.06 & 95.96 & & 95.88 & & 95.19 & & 93.40 & & \\
\hline $\mathrm{Si}$ & 0.001 & 0.001 & 0.00 & 0.004 & 0.003 & 0.000 & & & & \\
\hline $\mathrm{Al}^{\mathrm{vi}}$ & 0.096 & 0.084 & 0.00 & 0.075 & 0.004 & 0.080 & 0.021 & 0.033 & 0.020 & \\
\hline $\mathrm{Fe}^{3+}$ & 1.339 & 1.194 & 0.01 & 1.142 & 0.020 & 1.100 & 0.089 & 0.239 & 0.038 & \\
\hline $\mathrm{Ti}$ & 0.281 & 0.360 & 0.01 & 0.388 & 0.012 & 0.410 & 0.045 & 0.864 & 0.028 & \\
\hline $\mathrm{Cr}$ & 0.002 & & & & & & & & & \\
\hline $\mathrm{Fe}^{2+}$ & 1.087 & 1.055 & 0.01 & 1.052 & 0.017 & 1.058 & 0.039 & 0.628 & 0.018 & \\
\hline $\mathrm{Ni}$ & 0.003 & 0.001 & 0.00 & 0.001 & 0.001 & 0.002 & 0.002 & 0.003 & 0.004 & \\
\hline $\mathrm{Mn}$ & 0.003 & 0.006 & 0.00 & 0.008 & 0.002 & 0.011 & 0.003 & 0.004 & 0.002 & \\
\hline $\mathrm{Mg}$ & 0.189 & 0.298 & 0.01 & 0.330 & 0.014 & 0.339 & 0.011 & 0.229 & 0.042 & \\
\hline
\end{tabular}

Note: $\mathrm{TFeO}=$ total $\mathrm{Fe}^{2+}$. Averaged number of analyses in parentheses. Baima* is the calculated primary oxide (PO) composition from Shellnutt and Pang (2012). 
Table 4. Average composition of the clinopyroxene.

\begin{tabular}{|c|c|c|c|c|c|c|}
\hline Sample & BM-026 & s.d. & BM-027 & s.d. & BM0-007 & s.d. \\
\hline Temp. $\left({ }^{\circ} \mathrm{C}\right)$ & 1180 & (3) & 1159 & (7) & 1125 & (8) \\
\hline $\mathrm{SiO}_{2}(\mathrm{wt} \%)$ & 46.29 & 0.51 & 48.19 & 1.24 & 51.72 & 0.78 \\
\hline $\mathrm{TiO}_{2}$ & 1.33 & 0.08 & 1.37 & 0.20 & 0.28 & 0.11 \\
\hline $\mathrm{Al}_{2} \mathrm{O}_{3}$ & 5.17 & 0.51 & 4.35 & 0.63 & 1.12 & 0.81 \\
\hline $\mathrm{FeO}$ & 9.59 & 0.24 & 8.34 & 1.14 & 11.33 & 0.88 \\
\hline $\mathrm{MnO}$ & 0.15 & 0.01 & 0.24 & 0.06 & 0.32 & 0.04 \\
\hline $\mathrm{MgO}$ & 13.59 & 0.30 & 14.58 & 1.25 & 11.60 & 0.38 \\
\hline $\mathrm{CaO}$ & 22.20 & 0.26 & 22.12 & 0.16 & 21.44 & 0.77 \\
\hline $\mathrm{Na}_{2} \mathrm{O}$ & 0.67 & 0.08 & 0.65 & 0.07 & 0.78 & 0.26 \\
\hline $\mathrm{K}_{2} \mathrm{O}$ & 0.01 & 0.01 & 0.01 & 0.01 & 0.08 & 0.14 \\
\hline Total & 99.00 & & 99.85 & & 98.66 & \\
\hline \multicolumn{7}{|c|}{ Cations on the Basis of 60} \\
\hline $\mathrm{Si}$ & 1.774 & 0.018 & 1.830 & 0.041 & 1.981 & 0.015 \\
\hline $\mathrm{Al}^{\mathrm{iv}}$ & 0.226 & 0.018 & 0.165 & 0.048 & 0.019 & 0.015 \\
\hline $\mathrm{Al}^{\mathrm{vi}}$ & 0.007 & 0.006 & 0.006 & 0.006 & 0.031 & 0.033 \\
\hline $\mathrm{Fe}^{3+}$ & 0.282 & 0.013 & 0.202 & 0.044 & 0.049 & 0.038 \\
\hline $\mathrm{Ti}$ & 0.038 & 0.003 & 0.039 & 0.007 & 0.008 & 0.003 \\
\hline $\mathrm{Fe}^{2+}$ & 0.018 & 0.016 & 0.042 & 0.044 & 0.312 & 0.042 \\
\hline Mn & 0.005 & 0.001 & 0.008 & 0.002 & 0.011 & 0.002 \\
\hline $\mathrm{Mg}$ & 0.777 & 0.013 & 0.825 & 0.057 & 0.662 & 0.020 \\
\hline $\mathrm{Ca}$ & 0.912 & 0.014 & 0.901 & 0.033 & 0.880 & 0.040 \\
\hline $\mathrm{Na}$ & 0.050 & 0.006 & 0.048 & 0.006 & 0.058 & 0.018 \\
\hline $\mathrm{K}$ & 0.000 & 0.001 & 0.000 & 0.000 & 0.004 & 0.007 \\
\hline Wo & 46 & 0.01 & 46 & 0.02 & 46 & 0.01 \\
\hline En & 39 & 0.01 & 42 & 0.03 & 35 & 0.02 \\
\hline Fs & 15 & 0.00 & 12 & 0.03 & 19 & 0.01 \\
\hline
\end{tabular}

Note: Mineral symbols: En = Enstatite component $;$ Fs = ferrosilite component; Wo = wollastonite component. s.d. = standard deviation. Number in parenthesis is the total number of analysis.

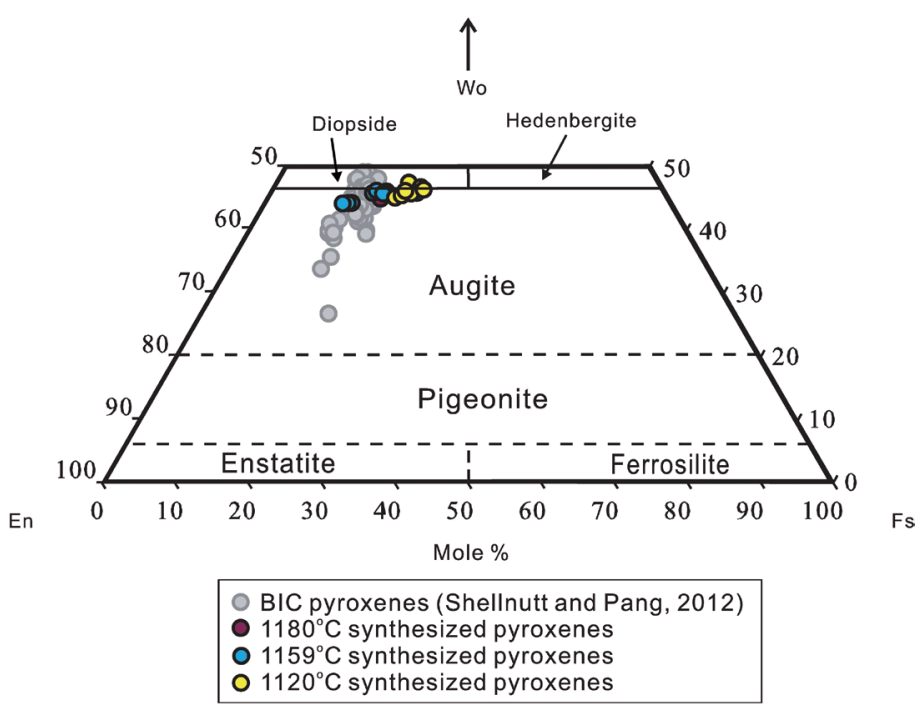

Fig. 4. Chemical classification of the experimental clinopyroxene in comparison to the clinopyroxene from the Baima layered gabbro. 
content ranges from 0.2 to $1.7 \mathrm{wt} \%$ and the $\mathrm{Al}_{2} \mathrm{O}_{3}$ content ranges from 0.5 to $5.7 \mathrm{wt} \%$.

The average composition of the plagioclase for each experiment ranges from labradorite $\left(\mathrm{An}_{65}\right)$ to andesine $\left(\mathrm{An}_{31}\right)$. The $\mathrm{Al}_{2} \mathrm{O}_{3}$ content is between 27.7 and $24.5 \mathrm{wt} \%$ whereas the $\mathrm{K}_{2} \mathrm{O}$ content ranges from 0.25 to $0.63 \mathrm{wt} \%$ (Fig. 5; Table 5). The total iron, expressed as FeOt, ranges from $2.6 \mathrm{wt} \%$ in the high temperature experiments to $0.4 \mathrm{wt} \%$ in the lowest temperature experiments.

The averaged compositions of the residual glass for each experiment are listed in Table 6 . The variation of the major element chemistry of the glass compositions versus temperature are plotted in Fig. 6. As the temperature decreased, the liquid line of descent shows an increase in $\mathrm{SiO}_{2}$, $\mathrm{Al}_{2} \mathrm{O}_{3}, \mathrm{Na}_{2} \mathrm{O}$, and $\mathrm{K}_{2} \mathrm{O}$ and decrease in $\mathrm{MgO}, \mathrm{TiO}_{2}$, and total $\mathrm{FeO}$. The $\mathrm{CaO}$ of the glass increased between 1305 and $1180^{\circ} \mathrm{C}$ and then decreased (lowest temperature). The crystallization trend shows that the residual liquid, as represented by the glass, became considerably depleted in $\mathrm{TiO}_{2}$ and total $\mathrm{FeO}$ as the temperature dropped below $1305^{\circ} \mathrm{C}$. The depletion was triggered by the crystallization of the Ti-rich magnetite. When the temperature reached $1180^{\circ} \mathrm{C}$, the $\mathrm{CaO}$ and $\mathrm{MgO}$ contents of the residual liquids became depleted as a result of the crystallization of clinopyroxene (Fig. 6).

The averaged trace elemental compositions of the glass from each run are listed in Table 7 . The concentrations of compatible elements of the residual glass are highly variable; for example: Sc (15.1 - $30.6 \mathrm{ppm})$, Ni (16.1 $54.8 \mathrm{ppm})$, and $\mathrm{Cr}(3.8$ - $26.1 \mathrm{ppm})$. The trace element evolution relative to silica of the glass is illustrated in Fig. 7. As the $\mathrm{SiO}_{2}$ content of the residual glasses increased (i.e., decrease in temperature) the amount of $\mathrm{Ba}, \mathrm{Rb}, \mathrm{Sr}, \mathrm{Nd}$, and $\mathrm{Zr}$ increased (Fig. 7). In comparison, the $\mathrm{Ni}$ and $\mathrm{Cr}$ decreased significantly between 1305 and $1159^{\circ} \mathrm{C}$.

\section{DISCUSSION}

\subsection{An Analogue for the Formation of the Baima Syenitic Unit?}

The Baima syenitic unit is considered to be representative a residual liquid derived by factional crystallization of a basaltic parental magma equal to high-Ti Emeishan basalt whereas the Baima layered gabbroic intrusion is considered to be the accumulated solid resulting from the same parental magma or batches of magma (Yang et al. 1997; Shellnutt et al. 2009, 2011; Shellnutt and Pang 2012; Zhang et al. 2012). Geological, mineralogical, and petrological evidence indicates the intrusion formed at low pressure $(\sim 0.1 \mathrm{GPa})$ and the relative oxidation state of the magmas was probably equal to or above the fayalite-magnetite-quartz ( $\triangle \mathrm{FMQ}$ 0 to +2 ) buffer (Shellnutt et al. 2009; Shellnutt and Iizuka 2012; Zhang et al. 2012). It is likely that the parental magma contained volatiles $\left(\mathrm{CO}_{2}, \mathrm{~F}, \mathrm{Cl}\right.$, and $\left.\mathrm{H}_{2} \mathrm{O}\right)$ due to the presence of titanite, bastnäsite, fluorite, and amphibole in the Baima syenite (Shellnutt et al. 2009; Shellnutt and lizuka 2011, 2012).

The resultant Ti-rich magnetite, clinopyroxene, and plagioclase crystallization in the model shows that the residual glass compositions reach moderately high $\mathrm{SiO}_{2}$ concentration ( $\geq 56 \mathrm{wt} \%$ ). However, the most evolved silicic

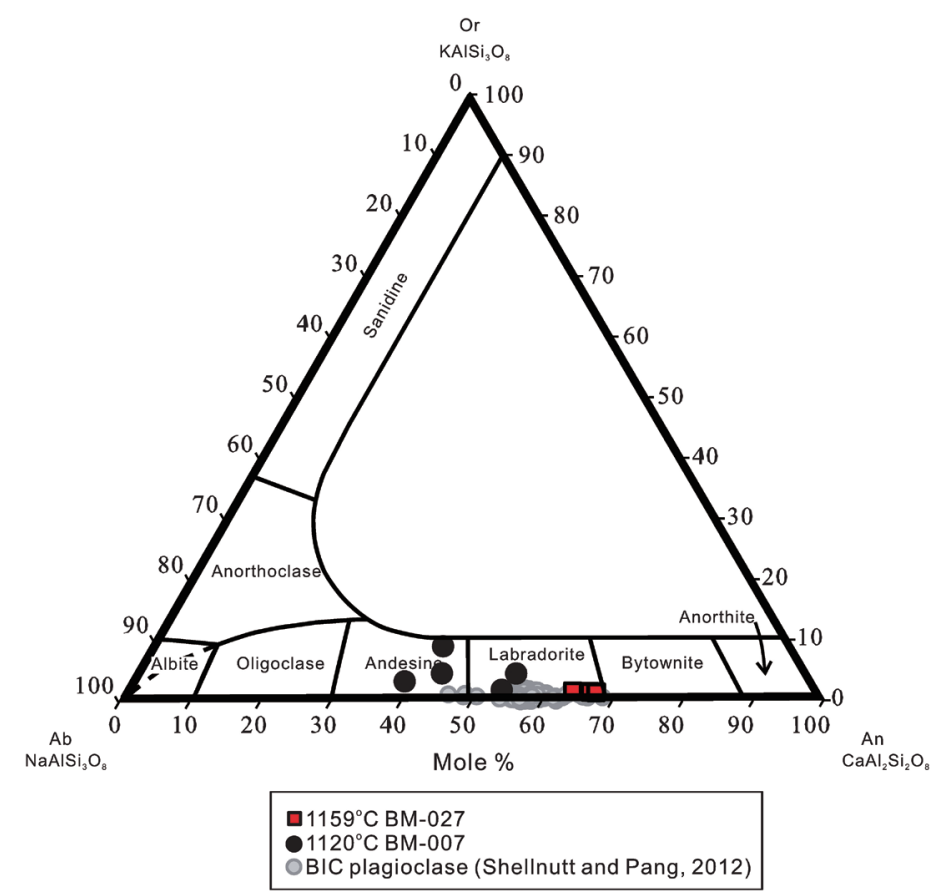

Fig. 5. Chemical classification of the experimental plagioclase in comparison to the plagioclase from the Baima layered gabbro. 
Table 5. Average compositions of the plagioclase.

\begin{tabular}{|c|c|c|c|c|}
\hline Sample & BM-027 & s.d. & BM-007 & s.d. \\
\hline Temp. $\left({ }^{\circ} \mathrm{C}\right)$ & 1159 & (3) & 1125 & (6) \\
\hline $\mathrm{SiO}_{2}(\mathrm{wt} \%)$ & 51.85 & 0.37 & 55.77 & 1.90 . \\
\hline $\mathrm{TiO}_{2}$ & 0.18 & 0.03 & 0.19 & 0.16 \\
\hline $\mathrm{Al}_{2} \mathrm{O}_{3}$ & 26.86 & 0.32 & 26.62 & 1.43 \\
\hline $\mathrm{FeO}$ & 2.53 & 0.05 & 0.95 & 0.51 \\
\hline $\mathrm{CaO}$ & 12.85 & 0.20 & 8.92 & 1.70 \\
\hline $\mathrm{Na}_{2} \mathrm{O}$ & 3.91 & 0.18 & 5.45 & 0.91 \\
\hline $\mathrm{K}_{2} \mathrm{O}$ & 0.24 & 0.01 & 0.64 & 0.31 \\
\hline Total & 98.41 & & 98.54 & \\
\hline \multicolumn{5}{|c|}{ Cations on the Basis of 80} \\
\hline $\mathrm{Si}$ & 2.422 & 0.007 & 2.551 & 0.080 \\
\hline $\mathrm{Ti}$ & 0.006 & 0.001 & 0.007 & 0.006 \\
\hline $\mathrm{Al}$ & 1.478 & 0.013 & 1.435 & 0.074 \\
\hline $\mathrm{Fe}^{2+}$ & 0.099 & 0.002 & 0.036 & 0.020 \\
\hline $\mathrm{Ca}$ & 0.643 & 0.013 & 0.437 & 0.084 \\
\hline $\mathrm{Na}$ & 0.354 & 0.013 & 0.483 & 0.080 \\
\hline $\mathrm{K}$ & 0.014 & 0.001 & 0.038 & 0.018 \\
\hline Total & 5.016 & & 4.986 & 0.008 \\
\hline An & 64 & 0.01 & 46 & 0.09 \\
\hline $\mathrm{Ab}$ & 35 & 0.01 & 48 & 0.08 \\
\hline Or & 1 & 0.0 & 4 & 0.02 \\
\hline
\end{tabular}

Note: Minerals symbols: $A n=$ anorthite component; $A b=$ albite component; Or = orthoclase component. s.d. $=$ standard deviation. Number in parenthesis is the total number of analysis.

Table 6. Average compositions of the glass and the Baima enclaves.

\begin{tabular}{ccccccccccccccc}
\hline Sample & BM-023 & s.d. & BM-005 & s.d. & BM-026 & s.d. & BM-027 & s.d. & BM-007 & s.d. & BM-1 & BM-2 & BM-4 & BM-5 \\
\hline $\mathrm{Temp} .\left({ }^{\circ} \mathrm{C}\right)$ & 1310 & $(74)$ & 1300 & $(73)$ & 1180 & $(6)$ & 1159 & $(7)$ & 1125 & $(4)$ & & & \\
$\mathrm{SiO}_{2}(\mathrm{wt} \%)$ & 45.66 & 0.26 & 46.61 & 0.37 & 51.47 & 0.22 & 53.59 & 0.78 & 57.58 & 0.39 & 58.12 & 62.94 & 60.08 & 57.20 \\
$\mathrm{TiO}_{2}$ & 4.01 & 0.10 & 3.98 & 0.12 & 2.91 & 0.12 & 2.54 & 0.32 & 2.04 & 0.22 & 1.46 & 0.77 & 1.03 & 1.80 \\
$\mathrm{Al}_{2} \mathrm{O}_{3}$ & 12.34 & 0.28 & 12.56 & 0.23 & 13.90 & 0.19 & 13.74 & 1.16 & 15.14 & 0.46 & 16.19 & 16.98 & 16.36 & 14.18 \\
$\mathrm{Cr}_{2} \mathrm{O}_{3}$ & & & 0.01 & 0.02 & - & - & - & - & 0.01 & 0.01 & & & \\
$\mathrm{FeOt}$ & 14.67 & 0.19 & 14.41 & 0.20 & 7.16 & 0.23 & 6.32 & 0.29 & 4.81 & 0.33 & 5.44 & 3.81 & 4.84 & 7.19 \\
$\mathrm{MnO}$ & 0.20 & 0.04 & 0.20 & 0.04 & 0.20 & 0.04 & 0.19 & 0.05 & 0.14 & 0.03 & 0.22 & 0.19 & 0.22 & 0.37 \\
$\mathrm{MgO}$ & 6.07 & 0.08 & 6.06 & 0.09 & 5.88 & 0.11 & 5.25 & 0.79 & 3.83 & 0.47 & 2.45 & 0.84 & 1.79 & 2.61 \\
$\mathrm{CaO}$ & 9.77 & 0.10 & 9.87 & 0.12 & 10.45 & 0.18 & 9.49 & 1.00 & 6.10 & 0.60 & 3.28 & 1.70 & 3.04 & 3.17 \\
$\mathrm{Na}{ }_{2} \mathrm{O}$ & 3.46 & 0.07 & 3.31 & 0.07 & 3.84 & 0.06 & 4.36 & 0.37 & 4.18 & 0.27 & 7.17 & 7.52 & 7.38 & 6.59 \\
$\mathrm{~K}_{2} \mathrm{O}$ & 1.17 & 0.03 & 1.16 & 0.03 & 1.38 & 0.03 & 1.69 & 0.13 & 2.84 & 0.32 & 3.88 & 4.66 & 4.22 & 4.16 \\
$\mathrm{Total}$ & 97.04 & & 97.16 & & 97.80 & & 97.19 & & 96.66 & & 98.21 & 99.41 & 98.96 & 97.27 \\
\hline $\mathrm{Mg} \#$ & 42 & & 43 & & 59 & & 60 & & 59 & & 44 & 28 & 40 & 39 \\
\hline
\end{tabular}

Note: Enclave data from Shellnutt et al. (2010). FeOt of the Baima enclaves is calculated from $\mathrm{Fe}_{2} \mathrm{O}_{3} \mathrm{t}\left(\mathrm{FeOt}=0.8998 \times \mathrm{Fe}_{2} \mathrm{O}_{3} \mathrm{t}\right)$. 
(a)

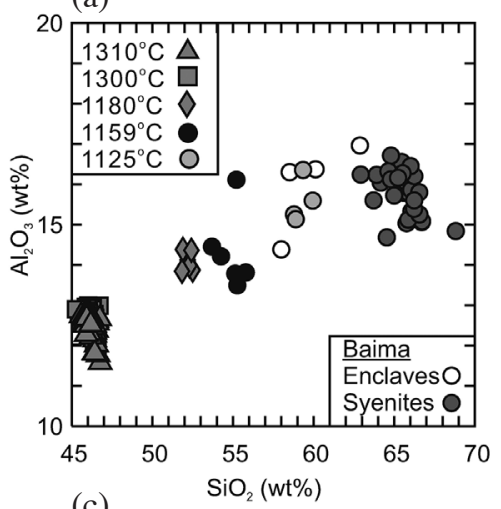

(c)

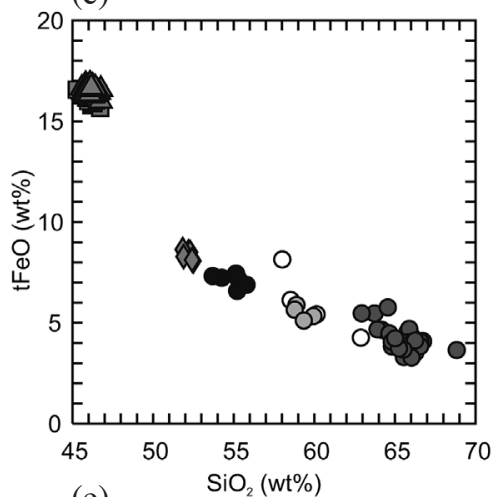

(e)

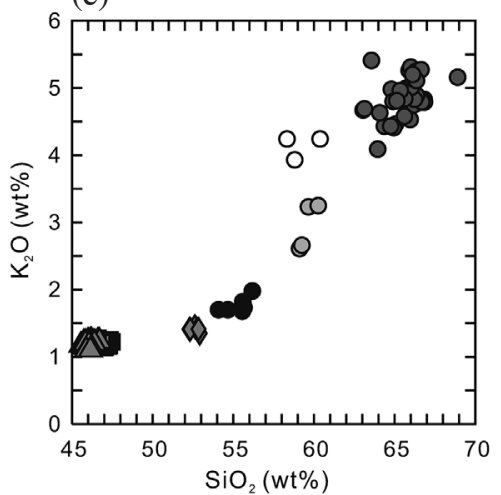

(b)

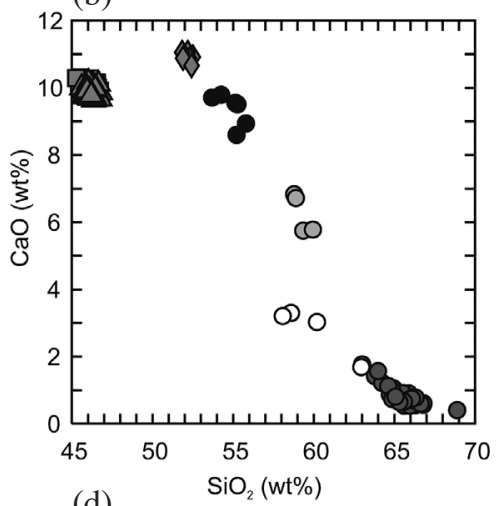

(d)

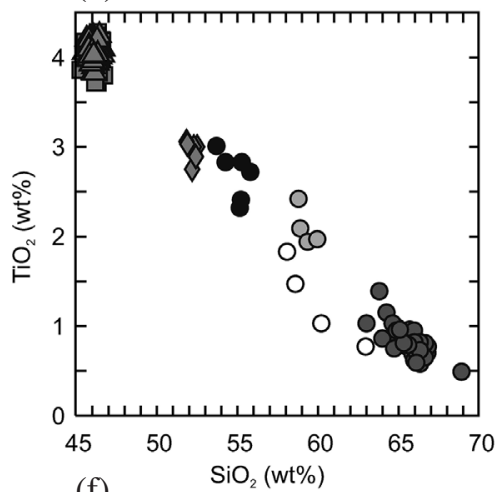

(f)

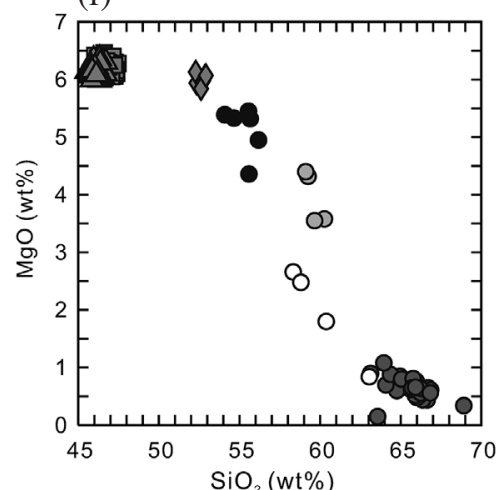

Fig. 6. Major element compositions of the glass from each run at low pressure. All data normalized to $100 \%$. Baima syenite and enclave data from Shellnutt et al. $(2009,2010)$. 
Table 7. Average whole rock trace elemental compositions of the glass.

\begin{tabular}{|c|c|c|c|c|c|c|c|c|c|c|c|}
\hline Sample & GS04-026 & BM-023 & s.d. & BM-005 & s.d. & BM-026 & s.d. & BM-027 & s.d. & BM-007 & s.d. \\
\hline Temp. $\left({ }^{\circ} \mathrm{C}\right)$ & & 1310 & (9) & 1300 & (3) & 1180 & (2) & 1159 & (2) & 1125 & (3) \\
\hline $\mathrm{Ca}(\mathrm{wt} \%)$ & 10.16 & 9.70 & 0.05 & 9.79 & 0.07 & 10.65 & 0.25 & 9.36 & 0.19 & 6.67 & 1.53 \\
\hline $\mathrm{Sc}(\mathrm{ppm})$ & 33 & 30.6 & 0.4 & 30.9 & 0.4 & 24.6 & 1.3 & 22.1 & 1.6 & 15.1 & 1.4 \\
\hline $\mathrm{Cr}$ & 26 & 26.1 & 4.3 & 22.1 & 0.3 & 4.2 & 0.2 & 3.8 & 0.3 & 10.7 & 4.6 \\
\hline $\mathrm{Ni}$ & 61 & 54.8 & 0.9 & 51.4 & 1.1 & 21.7 & 0.6 & 16.1 & 0.6 & 22.1 & 12.1 \\
\hline $\mathrm{Rb}$ & 62 & 69.4 & 1.3 & 68.0 & 1.2 & 80.8 & 2.7 & 93.9 & 6.1 & 89.4 & 35.3 \\
\hline $\mathrm{Sr}$ & 401 & 429 & 6.8 & 423 & 6.2 & 507 & 24.1 & 509 & 5.4 & 453 & 231 \\
\hline Y & 26 & 25.8 & 0.7 & 26.0 & 0.5 & 28.5 & 1.3 & 31.7 & 0.3 & 24.3 & 10.0 \\
\hline $\mathrm{Zr}$ & 165 & 173 & 5.9 & 174 & 3.2 & 194 & 24.9 & 215 & 34.2 & 152 & 119 \\
\hline $\mathrm{Nb}$ & 21 & 24.2 & 0.6 & 23.5 & 0.2 & 28.4 & 2.0 & 29.0 & 0.2 & 21.9 & 10.1 \\
\hline $\mathrm{Ba}$ & 310 & 321 & 7.7 & 313 & 6.7 & 369 & 19.5 & 422 & 11.2 & 405 & 112 \\
\hline $\mathrm{La}$ & 24.5 & 24.5 & 0.7 & 23.9 & 0.5 & 28.1 & 1.5 & 31.4 & 0.7 & 27.4 & 10.3 \\
\hline $\mathrm{Ce}$ & 54.2 & 55.0 & 1.3 & 53.0 & 1.2 & 63.7 & 2.8 & 70.1 & 1.7 & 60.3 & 23.2 \\
\hline $\operatorname{Pr}$ & 7.2 & 7.4 & 0.2 & 7.1 & 0.2 & 8.5 & 0.4 & 9.4 & 0.3 & 7.7 & 3.1 \\
\hline $\mathrm{Nd}$ & 30.5 & 31.8 & 0.8 & 30.6 & 0.7 & 36.1 & 2.0 & 40.1 & 0.7 & 31.9 & 12.9 \\
\hline $\mathrm{Sm}$ & 6.8 & 6.9 & 0.2 & 6.6 & 0.2 & 7.7 & 0.5 & 8.7 & 0.5 & 6.4 & 2.5 \\
\hline $\mathrm{Eu}$ & 2.2 & 2.2 & 0.1 & 2.2 & 0.1 & 2.5 & 0.1 & 2.8 & 0.1 & 2.3 & 0.7 \\
\hline $\mathrm{Gd}$ & 6.0 & 6.3 & 0.2 & 6.3 & 0.1 & 7.0 & 0.2 & 7.6 & 0.2 & 5.8 & 2.5 \\
\hline $\mathrm{Tb}$ & 1.0 & 0.9 & 0.0 & 0.9 & 0.0 & 1.0 & 0.1 & 1.1 & 0.0 & 0.8 & 0.3 \\
\hline Dy & 5.5 & 5.4 & 0.1 & 5.4 & 0.2 & 5.9 & 0.3 & 6.6 & 0.3 & 5.1 & 1.9 \\
\hline Ho & 1.0 & 1.0 & 0.0 & 1.0 & 0.0 & 1.1 & 0.1 & 1.3 & 0.0 & 0.9 & 0.3 \\
\hline Er & 2.8 & 2.6 & 0.1 & 2.6 & 0.1 & 3.0 & 0.2 & 3.1 & 0.2 & 2.4 & 1.0 \\
\hline $\mathrm{Tm}$ & 0.4 & 0.3 & 0.0 & 0.4 & 0.0 & 0.4 & 0.0 & 0.4 & 0.0 & 0.3 & 0.1 \\
\hline $\mathrm{Yb}$ & 2.3 & 2.2 & 0.1 & 2.4 & 0.2 & 2.5 & 0.2 & 2.6 & 0.1 & 2.1 & 0.7 \\
\hline $\mathrm{Lu}$ & 0.3 & 0.3 & 0.0 & 0.3 & 0.0 & 0.3 & 0.0 & 0.4 & 0.0 & 0.3 & 0.1 \\
\hline $\mathrm{Hf}$ & 4.6 & 4.6 & 0.1 & 4.5 & 0.2 & 4.8 & 0.6 & 5.6 & 1.0 & 3.6 & 2.6 \\
\hline $\mathrm{Ta}$ & 1.5 & 1.5 & 0.1 & 1.5 & 0.0 & 1.8 & 0.2 & 1.7 & 0.0 & 1.1 & 0.4 \\
\hline
\end{tabular}



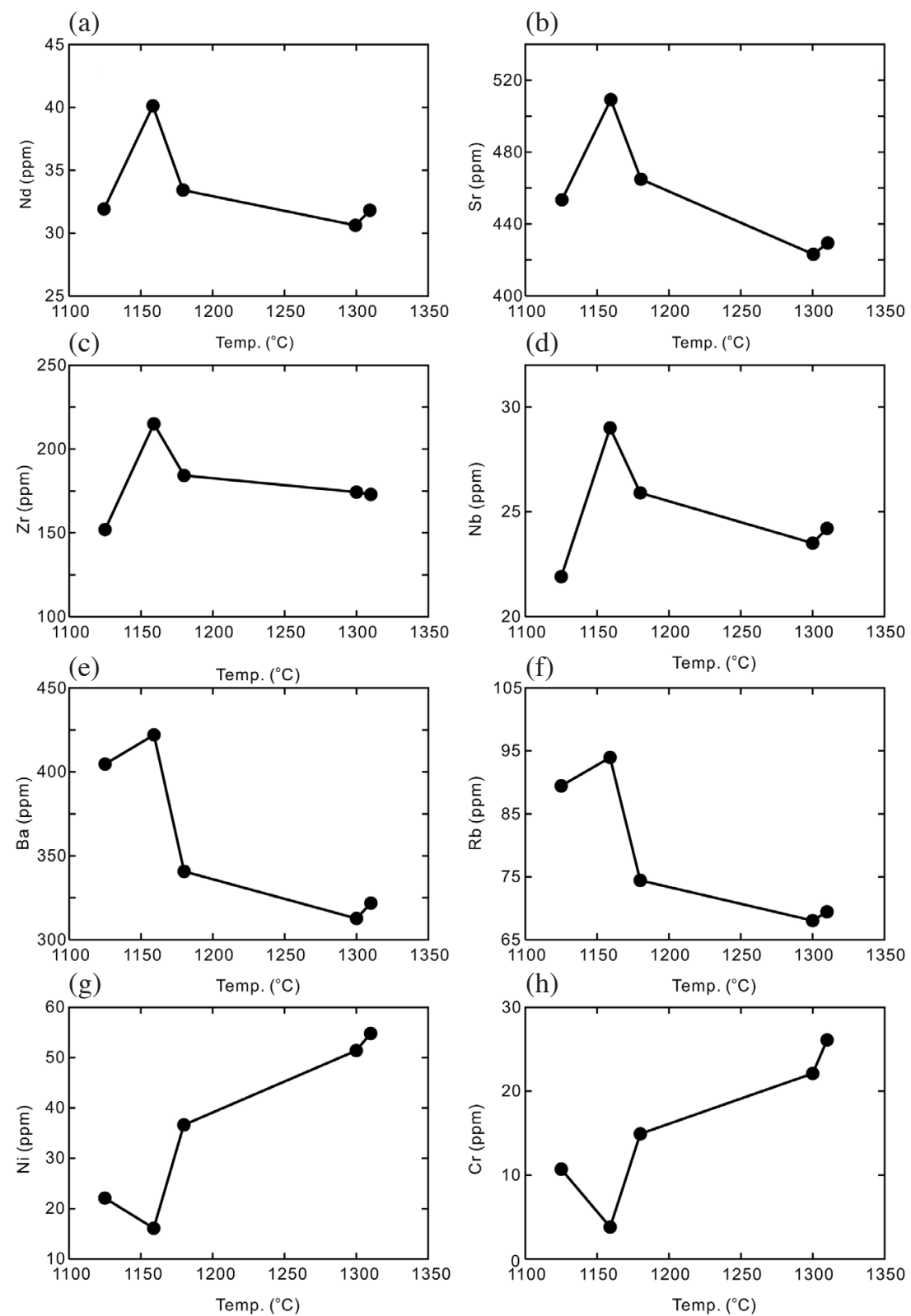

Fig. 7. Trace element compositions of the glass from each experiment at low pressure. 
glasses are more similar in composition to the observed enclaves of the BIC syenitic unit (Fig. 6; Table 6). The microgranular enclaves are considered to be representative of the most primitive composition of the syenitic rocks before further differentiation to more silicic $\left(\mathrm{SiO}_{2}>62 \mathrm{wt} \%\right)$ compositions (Shellnutt et al. 2010). The $\mathrm{Na}_{2} \mathrm{O}$ (lower; Table 6) and $\mathrm{CaO}$ (higher; Fig. 6) contents of the glass compositions are different from the enclaves but this is probably due to the anhydrous nature of the experiments as $\mathrm{F}, \mathrm{Cl}, \mathrm{CO}_{2}$, and $\mathrm{H}_{2} \mathrm{O}$ tend to increase the incompatibility of $\mathrm{Na}$ and rare earth elements and promote the crystallization of volatile-rich accessory minerals such as fluorite, bastnäsite, and titanite (Price et al. 1999; Scaillet and Macdonald 2004; Gysi and Williams-Jones 2015). The incompatible trace element evolution mirrors the major element composition. As the glass becomes more silicic, the incompatible (REE, $\mathrm{Nb}, \mathrm{Ta}$ ) trace elements become more enriched whereas the compatible (Ni, Cr, Sc) elements become depleted (Fig. 7).

The incompatible trace element evolution of the system is typified by $\mathrm{Sr}$ and $\mathrm{Ba}$ and resembles the geochemical modeling results of the Panxi gabbro-granitoid complexes (Fig. 8a). The geochemical models of the Panxi gabbrogranitoid complexes show that both $\mathrm{Sr}$ and $\mathrm{Ba}$ initially increase after early crystallization of titanomagnetite and mafic silicate minerals, and is followed by the decrease of $\mathrm{Sr}$ and increase of $\mathrm{Ba}$ due to the crystallization of plagioclase feldspar and then the decrease of both $\mathrm{Sr}$ and $\mathrm{Ba}$ due to the crystallization of alkali feldspar (Shellnutt et al. 2009, 2011; Shellnutt and Jahn 2010). A similar evolutionary path for $\mathrm{Sr}$ and $\mathrm{Ba}$ is shown in the low pressure models where $\mathrm{Sr}$ and $\mathrm{Ba}$ initially increase followed by a decrease in $\mathrm{Sr}$ and increase $\mathrm{Ba}$ (Fig. 8b). The two data points for the $1125^{\circ} \mathrm{C}$ experiment have very different compositions and thus it is difficult to reconcile their individual importance. We view the low $\mathrm{Sr}-\mathrm{Ba}$ composition $(\mathrm{Sr}=\sim 260 \mathrm{ppm}$; $\mathrm{Ba}$ $=\sim 300 \mathrm{ppm})$ as anomalous as there is no indication of alkali feldspar crystallization in the system but there is no analytical reason to reject the data and therefore it may be meaningful. The similarity between the $\mathrm{Sr}$-Ba experimental models and the geochemical models is supportive of the interpretation that the Baima syenite is derived from a parental magma similar to 'high-Ti' Emeishan basalt.

\subsection{Implications for the Genesis of the Baima Oxide- Bearing Layered Gabbroic Intrusion}

The Baima layered gabbroic intrusion is chiefly comprised of cumulus olivine, clinopyroxene, and plagioclase with interstitial Fe-Ti oxide and sulphide minerals. The oxide minerals periodically form thick ore-layers with the thickest layer near the base of the intrusion (Pang et al. 2010). Also, there is a distinct apatite-rich zone in the upper parts of the intrusion (Chen 1990; Shellnutt et al. 2009; Shellnutt and Pang 2012; Zhang et al. 2012; Chen et al. 2014; Liu et al. 2014a). It is interpreted that the Baima layered gabbroic intrusion and oxide deposit represent the solid residual portion of the parental magma or magmas that formed the Baima syenite (Yang et al. 1997; Shellnutt et al. 2009, 2011; Shellnutt and Pang 2012; Zhang et al. 2012). Therefore, if the modeled residual glass composition can replicate the observed Baima syenite microgranular enclaves then it is possible that the residual solid component may be able to shed light on the formation, textures, and structures observed in the layered gabbroic unit.

The composition of the Ti-rich magnetite is similar to the measured compositions from the Baima layered gabbro and the theorized primary oxide composition suggested by Shellnutt and Pang (2012). The compositions of the pyroxene and plagioclase are compared to the compositions analyzed from BIC layered gabbro in Figs. 4 and 5. The (a)

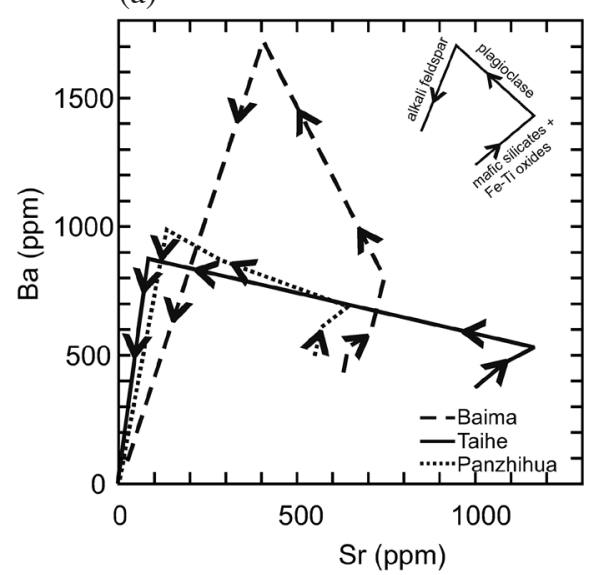

(b)

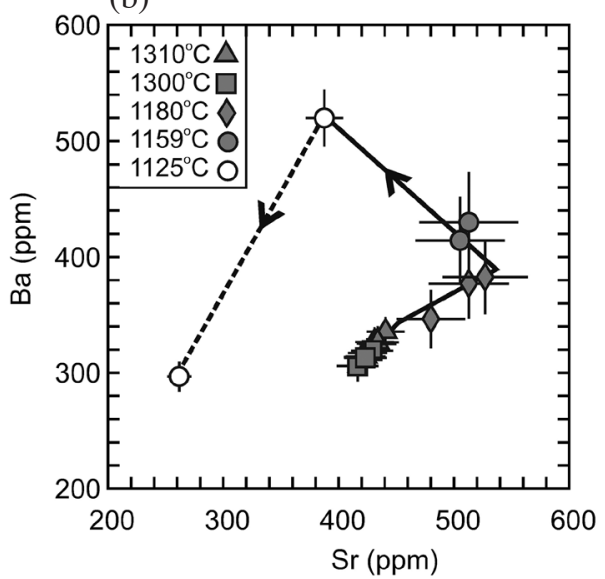

Fig. 8. (a) Geochemical models of Sr versus Ba evolution in the Baima, Panzhihua, and Taihe complexes (Shellnutt et al. 2009, 2010, 2011). (b) Experimental trend of $\mathrm{Sr}$ and $\mathrm{Ba}$ of the glass compositions. The dashed line connecting the low temperature compositions indicates an uncertain pathway (see text for details). 
clinopyroxene and plagioclase crystals have similar compositions as those observed in the BIC gabbros. Specifically, the compositional range of the modeled clinopyroxene at 1180 and $1159^{\circ} \mathrm{C}$ overlap with the clinopyroxene from the gabbros whereas the lower temperature $\left(1125^{\circ} \mathrm{C}\right)$ crystals tend to be more Fe-rich. The synthesized plagioclase, at all temperatures, is indistinguishable from the plagioclase of the gabbro (Fig. 5).

The early crystallization of titanomagnetite in the experiments is interesting as it may explain two important aspects of the layered gabbro. Firstly, early titanomagnetite crystallization explains the position of the oxide deposits within the lower parts of the layered gabbro. Moreover, it is possible that each Fe-Ti-rich horizon could represent an injection of a new batch of magma and the beginning of a new crystallization sequence as there is evidence for magma recharge in the system (Chen 1990; Shellnutt and Pang 2012; Zhang et al. 2012; Liu et al. 2014a). Secondly, mineral textures observed in the gabbro where silicate minerals and/or melt are enclosed by titanomagnetite and vice versa are replicated (Fig. 9). The application of QUIlF on the ilmenite-magnetite pairs of the lowest temperature runs indicates the relative oxidation state was above the FMQ buffer and ranges from $\triangle \mathrm{FMQ}+0.3$ to +1 or approximately equal to the Ni-NiO buffer (Andersen et al. 1993). The relative oxidation state estimate is within the range interpreted for the BIC system (Shellnutt et al. 2009, 2011; Zhang et al. 2012; Song et al. 2013).

\subsection{Limitations of the Interpretations}

The results of the experiments appear to replicate many textural, mineralogical, and chemical aspects of the BIC layered gabbroic and silicic units but there are limitations. Chiefly among the limitations is the verisimilitude of a small-scale experiment ( $<1$ gram) and relating it to a largescale intrusion $\left(\approx 100 \mathrm{~km}^{3}\right)$. Although we selected a parental magma that is considered to be similar to the BIC system, the precise composition remains uncertain and it may have developed under polybaric conditions. Volatiles in the magma system are not constrained during the experiment but they are likely to play role as biotite and brown-hornblende are observed within the layered gabbro and magmatic fluorite is observed in the syenite.

The absence of olivine in the modeled crystallization sequence is an issue as the Baima layered gabbro contains olivine at various levels. However, sample GS04-026 does not contain olivine and thus its absence in the experiment is expected (Shellnutt et al. 2008). Moreover, sample GS04026 probably experienced fractionation of olivine before emplacement (i.e., polybaric crystallization) as it is more evolved than a primary liquid (Herzberg and Asimow 2008; Shellnutt and Pham 2018). In the lower layers of the gabbro there is abundant olivine but the amount decreases at higher positions within the stratigraphy (Chen 1990; Shellnutt et al. 2009; Shellnutt and Pang 2012). It is very likely that the initial parental magma of the Baima gabbro was (a)

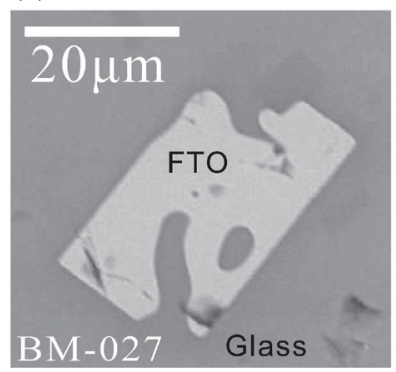

(b)

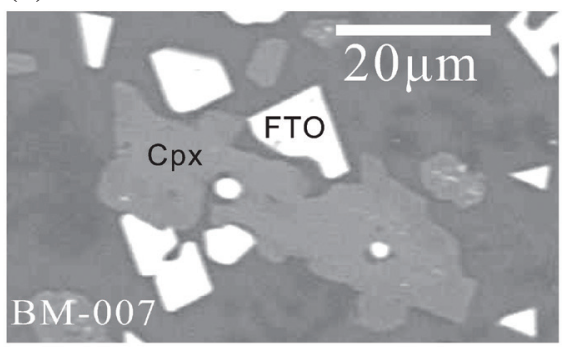

(c)

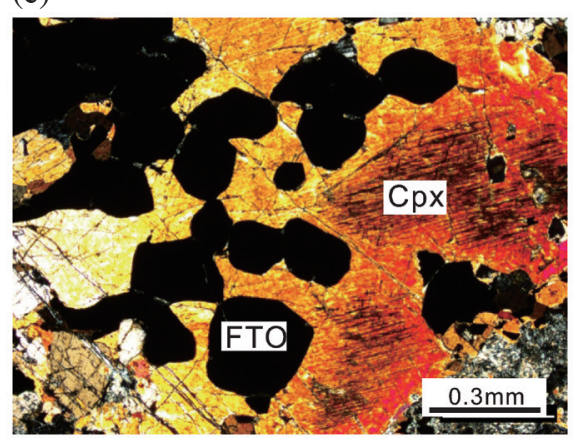

Fig. 9. (a) Iron-titanium oxide (FTO) mineral (Ti-magnetite) enclosing glass (Gl). (b) Clinopyroxene (Cpx) phenocryst enclosing Fe-Ti oxide (FTO) minerals. (c) Crossed polar photomicrograph of Ti-rich magnetite enclosed within clinopyroxene (Cpx) from the Panzhihua layered gabbro (courtesy of Kwan-Nang Pang). 
more primitive or closer to a primary liquid composition than GS04-026. Therefore, it is possible that subsequent injections of new magma batches, as delineated by mineral chemistry changes and oxide-rich layers, may have been less primitive and therefore crystallized less olivine. Consequently, the experiment may be a better example of the conditions and magma composition of the upper gabbro zone as it is comprised of clinopyroxene, plagioclase, ilmenite, and magnetite with little to no olivine. In spite of the limitations, the experimental results indicate that the BIC gabbro, syenite, and oxide deposit can be derived from a common parental magma similar to high-Ti Emeishan basalt.

\subsection{Role of Silicate Immiscibility and Carbonate Fluxing in the Formation of the BIC}

Recent studies have suggested that some of the Panxi oxide-ore deposits may be, at least partially, formed by silicate-liquid immiscibility and/or carbonate fluxing (Zhou et al. 2005, 2013; Ganino et al. 2008, 2013a, b; Liu et al. 2014a, 2016). The extent of silicate-liquid immiscibility vis-à-vis a large scale or small scale process is uncertain as the evidence for immiscibility is based on mineral or melt inclusion studies whereas carbonate fluxing is based on the contact relationship between the parental magma of the Panzhihua intrusion and marble country rock.

Experimental studies show that tholeiitic and alkalic basaltic liquids may enter conditions of silicate-liquid immiscibility after a period of crystal fractionation and produce an Fe-rich silicate liquid and a Si-rich silicate liquid (Philpotts 1976, 1982; Watson 1976; Naslund 1983; Veksler et al. 2007, 2008; Veksler 2009; Shellnutt et al. 2013). The bulk composition of the Si-rich silicate liquid is similar to granitic rocks in general whereas the Fe-rich silicate liquid resembles a mafic-ultramafic rock. The evidence for silicate immiscibility within the Panxi intrusions is based on observations and chemistry from mineral and melt inclusions and experimental results (Wang et al. 2013; Liu et al. 2014a, 2016; Hou and Veksler 2015; Xing et al. 2017). Although the evidence for small-scale silicate immiscibility is compelling, it is less clear that large-scale silicate immiscibility occurred. Specifically, there are a number of observations within the Baima layered gabbroic intrusion that cannot be easily explained by immiscibility and include: (1) systematic compositional evolution within the layered gabbro, (2) distribution of the incompatible elements in minerals or whole rock, and (3) the absence of a contemporaneous silicic plutonic body that is depleted in incompatible elements (Watson 1976; Veksler et al. 2006).

It appears that multiple magma pulses and internal redistribution occurred within the Baima system as the mineral composition trend is periodically interrupted but there is a broad systematic evolution from bottom to top where the base of the intrusion has more primitive compositions $(\mathrm{Fo} \approx$
$75 ; \mathrm{An} \approx 65)$ and the upper portions are more evolved $(\mathrm{Fo} \approx$ 60; An $\approx 50$ ) (Chen 1990; Shellnutt and Pang 2012; Zhang et al. 2012; Liu et al. 2014a). It is possible that the mineral compositional evolution may be due to injection of progressively less mafic basalts thereby creating the appearance of a systematic evolution but there is a distinct association between the composition of the minerals and their stratigraphic position. Assuming silicate-liquid immiscibility is not disturbed by the injection of new magma batches, there appears to be a dearth of highly calcic $(\mathrm{An}>80)$ plagioclase that would be expected to crystallize from the Fe-rich silicate liquid. If large-scale silicate immiscibility occurred then there should be layers or even a periodic discovery of coarse grained non-cumulus calcic plagioclase because the Fe-rich immiscible liquid is alkali-poor and relatively Ca-rich. To date, significant amounts of coarse grained, non-cumulus Ca-rich feldspar have yet to be identified by detailed mineralogical investigations (Chen 1990; Shellnutt and Pang 2012; Zhang et al. 2012; Liu et al. 2014a).

The results of trace element partitioning between the immiscible silicate melts by Watson (1976) and Veksler et al. (2006) showed that nearly all incompatible elements (Zr, $\mathrm{Hf}, \mathrm{Ti}, \mathrm{Nb}, \mathrm{Ta}$, and REEs) partition into the Fe-rich endmember due to its low polymerization and only $\mathrm{Rb}$ and $\mathrm{Cs}$ appear to prefer the Si-rich melt. The bulk rock compositions from different units of the Baima layered gabbro do not show unusually high concentrations of incompatible elements as most incompatible trace elements ( $\mathrm{Y}, \mathrm{Zr}, \mathrm{Hf}, \mathrm{Nb}$, Ta, and REEs) have concentrations $<10 \mathrm{ppm}$ (Shellnutt et al. 2009; Zhang et al. 2012). If the partition experiments of Watson (1976) and Veksler et al. (2006) are correct and that the thick oxide deposits formed due to immiscibility, then there should be zones or layers of equal volume to the oxiderich layers that contain the incompatible elements. At the moment, enriched zones or layers of REEs, $\mathrm{Y}, \mathrm{Ta}, \mathrm{Hf}, \mathrm{Zr}, \mathrm{Nb}$ have yet to be identified within the Baima layered gabbro.

Thus far, a large-scale plutonic body representing the Si-rich immiscible end-member has yet to be identified although Liu et al. (2016) suggest it could be the fayalitebearing syenite (Huangcao pluton) to the west of the Baima layered gabbro. The Huangcao syenite contains fayalite, ferrohedenbergite, alkali feldspar, quartz, apatite, ferrosilite, and Fe-Ti oxides (ilmenite and magnetite) and is considered to be formed by partial melting of underplated mafic rocks that are related to the Emeishan large igneous province (Shellnutt and Zhou 2008; Shellnutt and Iizuka 2012). The Huangcao pluton is probably not representative of the Si-rich immiscible melt because it demonstrates enrichment of $\mathrm{Ba}, \mathrm{Zr}, \mathrm{Ta}, \mathrm{Nb}$, and $\mathrm{REE}$ and depletion of Cs relative to the Baima layered gabbro and also has a positive chondrite normalized Eu-anomaly (Eu/Eu* > 1.1). If the Baima parental magma is required to undergo "prolonged fractional crystallization of plagioclase" before immiscibility then the resultant liquids should have either a neutral Eu-anomaly 
(i.e., $\mathrm{Eu} / \mathrm{Eu}^{*} \approx 1$ ) or, more likely, have a negative Eu-anomaly (Liu et al. 2016). Moreover, Fe-rich silicate minerals are a common feature of many ferroan (A-type) granites (Frost and Frost 1997, 2011; Civetta et al. 1998; Frost et al. 2001; Melluso et al. 2008).

An interesting result from the experiments of this study is the formation of inclusion textures of oxide minerals in clinopyroxene and vice versa (Fig. 9). Inclusion textures of oxides within silicates observed in the Baima layered gabbro are interpreted to be evidence of silicate immiscibility (Liu et al. 2014b, 2016). Based on our results, the inclusion textures form as a consequence of crystallization. Correspondingly, the early crystallization of oxide minerals in this study is likely directly related to the parental magma composition and relative oxidation state suggesting that some 'high-Ti' Emeishan mafic magmas are at or close to Fe-Ti saturation when they are emplaced and thus will preferentially crystallize titanomagnetite immediately upon cooling rather than silicate minerals. The early crystallization of titanomagnetite will therefore increase the likelihood that it will be enclosed by a silicate mineral.

Carbonate country rock assimilation, as observed by carbonate xenoliths within the Panzhihua layered intrusion, is suggested as a process for increasing the relative oxidation state of the Panxi oxide deposits and thereby inducing en masse crystallization of Fe-Ti oxide minerals (Ganino et al. 2008, 2013a, b; Bai et al. 2012; Pang et al. 2013; Tang et al. 2017). It is very likely that there was an interaction between carbonate country rocks and the magma that formed the Panzhihua complex as there are carbonate xenoliths found within the lower units of the gabbro. However, carbonate xenoliths are absent within in the Baima complex (Tang et al. 2017). It seems, from the experimental results, that carbonate assimilation may not be required to induce oxide mineral crystallization because the first mineral to crystallize from high-Ti Emeishan basalt is expected to be titanomagnetite at a relative oxidation state of $\triangle \mathrm{FMQ}+1$. The average relative oxidation state of all Emeishan basalt using the method of Kress and Carmichael (1991) is $\triangle F M Q$ +0.1 (total range $\triangle \mathrm{FMQ}-1.0$ to +1.3 ) (Shellnutt and lizuka 2012). Furthermore, the $\mathrm{Sr}$ isotopes of the Panxi layered gabbros do not appear to be highly enriched within the main body of the intrusion and suggests that contamination was probably a localized process around the contact margins (Shellnutt et al. 2009, 2011; Howarth and Prevec 2013). Therefore, assimilation of carbonate country rocks may be unnecessary to form the oxide deposits.

\section{CONCLUDING REMARKS}

The experiments resulted in a number of observations including:

(1) The crystallization sequence in the experiments is: Fe-Ti oxide $\left(1303^{\circ} \mathrm{C}\right)$; clinopyroxene $\left(1184^{\circ} \mathrm{C}\right)$; and plagio- clase $\left(1162^{\circ} \mathrm{C}\right)$.

(2) The compositions of the synthesized clinopyroxene and plagioclase are similar to the mineral compositions from the BIC layered gabbro.

(3) The residual glass compositions from the low temperature experiments are similar to the known composition of the Baima syenitic enclaves.

(4) Enclosure textures of oxide and silicate minerals in the gabbroic rocks are replicated in this study.

From the experimental observations we conclude that:

(1) The low pressure experiments were able to replicate the silicic enclave composition of the Baima syenitic unit, and the plagioclase and clinopyroxene compositions of the Baima layered gabbros. Therefore, it is possible that the layered gabbroic intrusion, oxide-ore deposit, and syenitic pluton of the BIC are a cogenetic complex that formed at low pressure.

(2) The Fe-Ti oxide deposits of the Baima layered gabbroic intrusion and possibly the Panzhihua and Taihe intrusions may have formed in situ and early during the crystallization of a basaltic parental magma. New batches of isotopically similar basaltic magmas were likely repeatedly injected into the same magma chamber and formed new Fe-Ti oxide horizons. Therefore, the presence of an oxide-dominant horizon within the layered gabbroic units may indicate a new magma pulse.

Acknowledgements We thank two anonymous reviewers for their comments that helped to improve the manuscript and Kuo-Lung Wang for editorial handling. The authors are appreciative of the laboratory assistance of Chian-Huei Hung, Hui-Ho Hsieh, and Yu-Shiang Wang. This research was supported by funding provided by Ministry of Science and Technology projects 107-2628-M-003-003-MY3 to JGS and 107-2116-M-003 to YI.

\section{REFERENCES}

Ali, J. R., G. M. Thompson, M.-F.Zhou, and X. Song, 2005: Emeishan large igneous province, SW China. Lithos, 79, 475-489, doi: 10.1016/j.lithos.2004.09.013. [Link]

Andersen, D. J., D. H. Lindsley, and P. M. Davidson, 1993: QUIIF: A Pascal program to assess equilibria among Fe-Mg-Mn-Ti oxides, pyroxenes, olivine, and quartz. Comput. Geosci., 19, 1333-1350, doi: 10.1016/00983004(93)90033-2. [Link]

Bai, Z.-J., H. Zhong, A. J. Naldrett, W.-G. Zhu, and G.W. Xu, 2012: Whole-rock and mineral composition constraints on the genesis of the giant Hongge Fe-Ti$\mathrm{V}$ oxide deposit in the Emeishan large igneous province, southwest China. Econ. Geol., 107, 507-524, doi: 10.2113/econgeo.107.3.507. [Link]

Bai, Z.-J., H. Zhong, C. Li, W.-G. Zhu, D.-F. He, and L. Qi, 2014: Contrasting parental magma compositions for 
the Hongge and Panzhihua magmatic Fe-Ti-V oxide deposits, Emeishan large igneous province, SW China. Econ. Geol., 109, 1763-1785, doi: 10.2113/econgeo.109.6.1763. [Link]

Bai, Z.-J., H. Zhong, C. Li, W.-G. Zhu, and W.-J. Hu, 2016: Association of cumulus apatite with compositionally unusual olivine and plagioclase in the Taihe Fe-Ti oxide ore-bearing layered mafic-ultramafic intrusion: Petrogenetic significance and implications for ore genesis. Am. Mineral., 101, 2168-2175, doi: 10.2138/am2016-5577. [Link]

Bonin, B., 2007: A-type granites and related rocks: Evolution of a concept, problems and prospects. Lithos, 97, 1-29, doi: 10.1016/j.lithos.2006.12.007. [Link]

Cawthorn, R. G., 1996: Layered Intrusions, Developments in Petrology, Vol. 15, Elsevier, Netherlands, 530 pp.

Charlier, B., O. Namur, R. Latypov, and C. Tegner, 2015: Layered Intrusions, Springer Netherlands, 748 pp, doi: 10.1007/978-94-017-9652-1. [Link]

Chen, F., 1990: Petrologic study on Baima ore-bearing layered mafic-ultramafic intrusion. Acta Petrologica Sinica, 4, 12-25. (in Chinese)

Chen, L.-M., X.-Y. Song, X.-K. Zhu, X.-Q. Zhang, S.-Y. Yu, and J.-N. Yi, 2014: Iron isotope fractionation during crystallization and sub-solidus re-equilibration: Constraints from the Baima mafic layered intrusion, SW China. Chem. Geol., 380, 97-109, doi: 10.1016/j. chemgeo.2014.04.020. [Link]

Chen, L.-M., X.-Y. Song, R.-Z. Hu, S.-Y. Yu, H.-L. He, Z.-H. Dai, Y.-W. She, and W. Xie, 2017: Controls on trace-element partitioning among co-crystallizing minerals: Evidence from the Panzhihua layered intrusion, SW China. Am. Mineral., 102, 1006-1020, doi: 10.2138/am-2017-5804. [Link]

Civetta, L., M. D’Antonio, G. Orsi, and G. R. Tilton, 1998: The geochemistry of volcanic rocks from Pantelleria Island, Sicily Channel: Petrogenesis and characteristics of the mantle source region. J. Petrol., 39, 14531491, doi: 10.1093/petroj/39.8.1453. [Link]

Duchesne, J. C., 1999: Fe-Ti deposits in Rogaland anorthosites (South Norway): Geochemical characteristics and problems of interpretation. Miner. Depos., 34, 182198, doi: 10.1007/s001260050195. [Link]

Frost, B. R., C. G. Barnes, W. J. Collins, R. J. Arculus, D. J. Ellis, and C. D. Frost, 2001: A geochemical classification for granitic rocks. J. Petrol., 42, 2033-2048.

Frost, C. D. and B. R. Frost, 1997: Reduced rapakivi-type granites: The tholeiite connection. Geology, 25, 647650, doi: 10.1130/0091-7613(1997)025<0647:RRTG TT>2.3.CO;2. [Link]

Frost, C. D. and B. R. Frost, 2011: On ferroan (A-type) granitoids: Their compositional variability and modes of origin. J.Petrol., 52, 39-53, doi: 10.1093/petrology/ egq070. [Link]
Ganino, C., N. T. Arndt, M.-F. Zhou, F. Gaillard, and C. Chauvel, 2008: Interaction of magma with sedimentary wall rock and magnetite ore genesis in the Panzhihua mafic intrusion, SW China. Miner. Depos., 43, 677-694, doi: 10.1007/s00126-008-0191-5. [Link]

Ganino, C., C. Harris, N. T. Arndt, S. A. Prevec, and G. H. Howarth, 2013a: Assimilation of carbonate country rock by the parent magma of the Panzhihua FeTi-V deposit (SW China): Evidence from stable isotopes. Geosci. Front., 4, 547-554, doi: 10.1016/j. gsf.2012.12.006. [Link]

Ganino, C., N. T. Arndt, C. Chauvel, A. Jean, and C. Athurion, 2013b: Melting of carbonate wall rocks and formation of the heterogeneous aureole of the Panzhihua intrusion, China. Geosci. Front., 4, 535-546, doi: 10.1016/j.gsf.2013.01.012. [Link]

Gysi, A. P. and A. E. Williams-Jones, 2015: The thermodynamic properties of bastnäsite-(Ce) and parisite(Ce). Chem. Geol., 392, 87-101, doi: 10.1016/j.chemgeo.2014.11.001. [Link]

Herzberg, C. and P. D. Asimow, 2008: Petrology of some oceanic island basalts: PRIMELT2.XLS software for primary magma calculation. Geochem. Geophys. Geosyst., 9, Q09001, doi: 10.1029/2008GC002057. [Link]

Hou, T. and I. V. Veksler, 2015: Experimental confirmation of high-temperature silicate liquid immiscibility in multicomponent ferrobasaltic systems. Am. Mineral., 100, 1304-1307, doi: 10.2138/am-2015-5285. [Link]

Howarth, G. H. and S. A. Prevec, 2013: Trace element, PGE, and Sr-Nd isotope geochemistry of the Panzhihua mafic layered intrusion, SW China: Constraints on ore-forming processes and evolution of parent magma at depth in a plumbing-system. Geochim. Cosmochim. Acta, 120, 459-478, doi: 10.1016/j.gca.2013.06.019. [Link]

Iyer, H. M., 1984: Geophysical evidence for the locations, shapes and sizes, and internal structures of magma chambers beneath regions of Quaternary volcanism. Phil. Trans. Roy. Soc. Lond. Math. Phys. Sci., 310, 473-510, doi: 10.1098/rsta.1984.0005. [Link]

Kress, V. C. and I. S. E. Carmichael, 1991: The compressibility of silicate liquids containing $\mathrm{Fe}_{2} \mathrm{O}_{3}$ and the effect of composition, temperature, oxygen fugacity and pressure on their redox states. Contrib. Mineral. Petrol., 108, 82-92, doi: 10.1007/bf00307328. [Link]

Lee, C. A., 1996: A review of mineralization in the Bushveld Complex and some other layered intrusions. In: Cawthorn, R. G. (Ed.), Layered Intrusions, Developments in Petrology, Vol. 15, Elsevier, Netherlands, 103-145, doi: 10.1016/S0167-2894(96)80006-6. [Link]

Liu, P.-P., M.-F. Zhou, C. Y. Wang, C.-M. Xing, and J.F. Gao, 2014a: Open magma chamber processes in the formation of the Permian Baima mafic-ultramafic layered intrusion, SW China. Lithos, 184-187, 194-208, 
doi: 10.1016/j.lithos.2013.10.028. [Link]

Liu, P.-P., M.-F. Zhou, W. T. Chen, M. Boone, and V. Cnudde, 2014b: Using multiphase solid inclusions to constrain the origin of the Baima Fe-Ti-(V) oxide deposit, SW China. J. Petrol., 55, 951-976, doi: 10.1093/ petrology/egu012. [Link]

Liu, P.-P., M.-F. Zhou, Z. Ren, C. Y. Wang, and K. Wang, 2016: Immiscible Fe- and Si-rich silicate melts in plagioclase from the Baima mafic intrusion (SW China): Implications for the origin of bi-modal igneous suites in large igneous provinces. J. Asian Earth Sci., 127, 211-230, doi: 10.1016/j.jseaes.2016.04.026. [Link]

Melluso, L., C. Cucciniello, C. M. Petrone, M. Lustrino, V. Morra, M. Tiepolo, and L. Vasconcelos, 2008: Petrology of Karoo volcanic rocks in the southern Lebombo monocline, Mozambique. J. Afr. Earth Sci., 52, 139151, doi: 10.1016/j.jafrearsci.2008.06.002. [Link]

Mondal, S. K. and W. L. Griffin, 2017: Processes and Ore Deposits of Ultramafic-Mafic Magmas through Space and Time, Elsevier, 382 pp.

Murru, M., C. Montuori, M. Wyss, and E. Privitera, 1999: The locations of magma chambers at Mt. Etna, Italy, mapped by b-values. Geophys. Res. Lett., 26, 25532556, doi: 10.1029/1999g1900568. [Link]

Naslund, H. R., 1983: The effect of oxygen fugacity on liquid immiscibility in iron-bearing silicate melts. Am.J. Sci., 283, 1034-1059, doi: 10.2475/ajs.283.10.1034. [Link]

Pang, K.-N. and J. G. Shellnutt, 2017: Magmatic sulfide and Fe-Ti oxide deposits associated with mafic-ultramafic intrusions in China. In: Mondal, S. K. and W. L. Griffin (Eds.), Processes and Ore Deposits of UltramaficMafic Magmas through Space and Time, Elsevier, 239-267.

Pang, K.-N., C. Li, M.-F. Zhou, and E. M. Ripley, 2008a: Abundant Fe-Ti oxide inclusions in olivine from the Panzhihua and Hongge layered intrusions, SW China: Evidence for early saturation of Fe-Ti oxides in ferrobasaltic magma. Contrib. Mineral. Petrol., 156,307321, doi: 10.1007/s00410-008-0287-z. [Link]

Pang, K.-N., M.-F. Zhou, D. Lindsley, D. Zhao, and J. Malpas, 2008b: Origin of Fe-Ti oxide ores in mafic intrusions: Evidence from the Panzhihua intrusion, SW China. J. Petrol., 49, 295-313, doi: 10.1093/petrology/ egm082. [Link]

Pang, K.-N., C. Li, M.-F. Zhou, and E. M. Ripley, 2009: Mineral compositional constraints on petrogenesis and oxide ore genesis of the late Permian Panzhihua layered gabbroic intrusion, SW China. Lithos, 110, 199214, doi: 10.1016/j.lithos.2009.01.007. [Link]

Pang, K.-N., M.-F. Zhou, L. Qi, J. G. Shellnutt, C. Y. Wang, and D. Zhao, 2010: Flood basalt-related Fe-Ti oxide deposits in the Emeishan large igneous province, SW China. Lithos, 119, 123-136, doi: 10.1016/j.lith- os.2010.06.003. [Link]

Pang, K.-N., N. Arndt, H. Svensen, S. Planke, A. Polozov, S. Polteau, Y. Iizuka, and S.-L. Chung, 2013: A petrologic, geochemical and Sr-Nd isotopic study on contact metamorphism and degassing of Devonian evaporites in the Norilsk aureoles, Siberia. Contrib. Mineral. Petrol., 165, 683-704, doi: 10.1007/s00410-012-0830-9. [Link]

Pêcher, A., N. Arndt, A. Jean, A. Bauville, C. Ganino, and C. Athurion, 2013: Structure of the Panzhihua intrusion and its Fe-Ti-V deposit, China. Geosci. Front., 4, 571-581, doi: 10.1016/j.gsf.2013.02.004. [Link]

Philpotts, A. R., 1967: Origin of certain iron-titanium oxide and apatite rocks. Econ. Geol., 62, 303-315, doi: 10.2113/gsecongeo.62.3.303. [Link]

Philpotts, A. R., 1976: Silicate liquid immiscibility: Its probable extent and petrogenetic significance. Am. J. Sci., 276, 1147-1177, doi: 10.2475/ajs.276.9.1147. [Link]

Philpotts, A. R., 1982: Compositions of immiscible liquids in volcanic rocks. Contrib. Mineral. Petrol., 80, 201218, doi: 10.1007/bf00371350. [Link]

Price, J. D., J. P. Hogan, M. C. Gilbert, D. London, and G. B. Morgan VI, 1999: Experimental study of titanite-fluorite equilibria in the A-type Mount Scott granite: Implications for assessing $\mathrm{F}$ contents of felsic magma. Geology, 27, 951-954, doi: 10.1130/0091-7613(1999)027<0951:ESOTFE>2.3. $\mathrm{CO} ; 2$. [Link]

Scaillet, B. and R. Macdonald, 2004: Fluorite stability in silicic magmas. Contrib. Mineral. Petrol., 147, 319-329, doi: 10.1007/s00410-004-0559-1. [Link]

She, Y.-W., S.-Y. Yu, X.-Y. Song, L.-M. Chen, W.-Q. Zheng, and Y. Luan, 2014: The formation of P-rich Fe-Ti oxide ore layers in the Taihe layered intrusion, SW China: Implications for magma-plumbing system process. Ore Geol. Rev., 57, 539-559, doi: 10.1016/j. oregeorev.2013.07.007. [Link]

Shellnutt, J. G., 2014: The Emeishan large igneous province: A synthesis. Geosci. Front., 5, 369-394, doi: 10.1016/j.gsf.2013.07.003. [Link]

Shellnutt, J. G. and Y. Iizuka, 2011: Mineralogy from three peralkaline granitic plutons of the Late Permian Emeishan large igneous province (SW China): Evidence for contrasting magmatic conditions of A-type granitoids. Eur. J. Mineral., 23, 45-61, doi: 10.1127/09351221/2010/0022-2073. [Link]

Shellnutt, J. G. and Y. Iizuka, 2012: Oxidation zonation within the Emeishan large igneous province: Evidence from mantle-derived syenitic plutons. J. Asian Earth Sci., 54-55, 31-40, doi: 10.1016/j.jseaes.2012.03.011. [Link]

Shellnutt, J. G. and B.-M. Jahn, 2010: Formation of the Late Permian Panzhihua plutonic-hypabyssal-volcanic igneous complex: Implications for the genesis of 
Fe-Ti oxide deposits and A-type granites of SW China. Earth Planet. Sci. Lett., 289, 509-519, doi: 10.1016/j. eps1.2009.11.044. [Link]

Shellnutt, J. G. and K.-N. Pang, 2012: Petrogenetic implications of mineral chemical data for the Permian Baima igneous complex, SW China. Mineral. Petrol., 106, 75-88, doi: 10.1007/s00710-012-0217-7. [Link]

Shellnutt, J. G. and T. T. Pham, 2018: Mantle potential temperature estimates and primary melt compositions of the Low-Ti Emeishan flood basalt. Front. Earth Sci., 6, doi: 10.3389/feart.2018.00067. [Link]

Shellnutt, J. G. and M.-F. Zhou, 2007: Permian peralkaline, peraluminous and metaluminous A-type granites in the Panxi district, SW China: Their relationship to the Emeishan mantle plume. Chem. Geol., 243, 286-316, doi: 10.1016/j.chemgeo.2007.05.022. [Link]

Shellnutt, J. G. and M.-F. Zhou, 2008: Permian, rifting related fayalite syenite in the Panxi region, SW China. Lithos, 101, 54-73, doi: 10.1016/j.lithos.2007.07.007. [Link]

Shellnutt, J. G., M.-F. Zhou, D.-P. Yan, and Y. Wang, 2008: Longevity of the Permian Emeishan mantle plume (SW China): $1 \mathrm{Ma}, 8 \mathrm{Ma}$ or $18 \mathrm{Ma}$ ? Geol. Mag., 145, 373-388, doi: 10.1017/S0016756808004524. [Link]

Shellnutt, J. G., M.-F. Zhou, and G. F. Zellmer, 2009: The role of $\mathrm{Fe}-\mathrm{Ti}$ oxide crystallization in the formation of A-type granitoids with implications for the Daly gap: An example from the Permian Baima igneous complex, SW China. Chem. Geol., 259, 204-217, doi: 10.1016/j. chemgeo.2008.10.044. [Link]

Shellnutt, J. G., B.-M. Jahn, and J. Dostal, 2010: Elemental and $\mathrm{Sr}-\mathrm{Nd}$ isotope geochemistry of microgranular enclaves from peralkaline A-type granitic plutons of the Emeishan large igneous province, SW China. Lithos, 119, 34-46, doi: 10.1016/j.lithos.2010.07.011. [Link]

Shellnutt, J. G., K.-L. Wang, G. F. Zellmer, Y. Iizuka, B.M. Jahn, K.-N. Pang, L. Qi, and M.-F. Zhou, 2011: Three Fe-Ti oxide ore-bearing gabbro-granitoid complexes in the Panxi region of the Permian Emeishan large igneous province, SW China. Am. J. Sci., 311, 773-812, doi: 10.2475/09.2011.02. [Link]

Shellnutt, J. G., S. W. Denyszyn, and R. Mundil, 2012: Precise age determination of mafic and felsic intrusive rocks from the Permian Emeishan large igneous province (SW China). Gondwana Res., 22, 118-126, doi: 10.1016/j.gr.2011.10.009. [Link]

Shellnutt, J. G., J. Dostal, and Y. Iizuka, 2013: Evidence of silicate immiscibility within flood basalts from the Central Atlantic Magmatic Province. Geochem. Geophys. Geosyst., 14, 4921-4935, doi: 10.1002/2013gc004977. [Link]

Shellnutt, J. G., G. S.-K. Ma, and L. Qi, 2015: Platinumgroup elemental chemistry of the Baima and Taihe FeTi oxide bearing gabbroic intrusions of the Emeishan large igneous province, SW China. Geochemistry, 75, 35-49, doi: 10.1016/j.chemer.2014.06.002. [Link]

Song, X.-Y., M.-F. Zhou, R. R. Keays, Z.-M. Cao, M. Sun, and L. Qi, 2006: Geochemistry of the Emeishan flood basalts at Yangliuping, Sichuan, SW China: Implications for sulfide segregation. Contrib. Mineral.Petrol., 152, 53-74, doi: 10.1007/s00410-006-0094-3. [Link]

Song, X.-Y., H.-W. Qi, R.-Z. Hu, L.-M. Chen, S.-Y. Yu, and J.-F. Zhang, 2013: Formation of thick stratiform $\mathrm{Fe}-\mathrm{Ti}$ oxide layers in layered intrusion and frequent replenishment of fractionated mafic magma: Evidence from the Panzhihua intrusion, SW China. Geochem. Geophys. Geosyst., 14, 712-732, doi: 10.1002/ ggge.20068. [Link]

Tang, Q., C. Li, Y. Tao, E. M. Ripley, and F. Xiong, 2017: Association of Mg-rich olivine with magnetite as a result of brucite marble assimilation by basaltic magma in the Emeishan large igneous province, SW China. $J$. Petrol., 58, 699-714, doi: 10.1093/petrology/egx031. [Link]

Van Tongeren, J. A. and E. A. Mathez, 2012: Largescale liquid immiscibility at the top of the Bushveld Complex, South Africa. Geology, 40, 491-494, doi: 10.1130/g32980.1. [Link]

Veksler, I. V., 2009: Extreme iron enrichment and liquid immiscibility in mafic intrusions: Experimental evidence revisited. Lithos, 111, 72-82, doi: 10.1016/j. lithos.2008.10.003. [Link]

Veksler, I. V., A. M. Dorfman, L. V. Danyushevsky, J. K. Jakobsen, and D. B. Dingwell, 2006: Immiscible silicate liquid partition coefficients: Implications for crystal-melt element partitioning and basalt petrogenesis. Contrib. Mineral. Petrol., 152, 685-702, doi: 10.1007/ s00410-006-0127-y. [Link]

Veksler, I. V., A. M. Dorfman, A. A. Borisov, R. Wirth, and D. B. Dingwell, 2007: Liquid immiscibility and the evolution of basaltic magma. J. Petrol., 48, 21872210, doi: 10.1093/petrology/egm056. [Link]

Veksler, I. V., A. M. Dorfman, D. Rhede, R. Wirth, A. A. Borisov, and D. B. Dingwell, 2008: Liquid unmixing kinetics and the extent of immiscibility in the system $\mathrm{K}_{2} \mathrm{O}-\mathrm{CaO}-\mathrm{FeO}-\mathrm{Al}_{2} \mathrm{O}_{3}-\mathrm{SiO}_{2}$. Chem. Geol., 256, 119130, doi: 10.1016/j.chemgeo.2008.06.033. [Link]

Wager, L. R. and G. M. Brown, 1968: Layered Igneous Rocks, Oliver and Boyd, Edinburgh, 588 pp.

Wang, C. Y., M.-F. Zhou, and L. Qi, 2007: Permian flood basalts and mafic intrusions in the Jinping (SW China)-Song Da (northern Vietnam) district: Mantle sources, crustal contamination and sulfide segregation. Chem. Geol., 243, 317-343, doi: 10.1016/j.chemgeo.2007.05.017. [Link]

Wang, D. R., Y. M. Xie, Q. J. Wang, and Z. D. Tao, 1994: Geology of Guabang area. Map G-48-25-C, Panxi Geological Team, Geology and Mineral Resources 
Bureau of Sichuan Province, 1:50000.

Wang, K., C. M. Xing, Z. Y. Ren, and Y. Wang, 2013: Liquid immiscibility in the Panzhihua mafic layered intrusion: Evidence from melt inclusions in apatite. Acta Petrologica Sinica, 29, 3503-3518. (in Chinese)

Watson, E. B., 1976: Two-liquid partition coefficients: Experimental data and geochemical implications. Contrib. Mineral. Petrol., 56, 119-134, doi: 10.1007/ bf00375424. [Link]

Xing, C.-M., C. Y. Wang, and W. Tan, 2017: Disequilibrium growth of olivine in mafic magmas revealed by phosphorus zoning patterns of olivine from mafic-ultramafic intrusions. Earth Planet. Sci. Lett., 479, 108119, doi: 10.1016/j.eps1.2017.09.005. [Link]

Xiong, X. Y., Y. M. Xie, K. H. Nie, Z. Z. Kan, L. R. Ding, and J. Q. Guo, 1996: Geology of Miyi area. Map G48-37-A, Geology and Mineral Resources Bureau of Sichuan Province, 1:50000.

Xu, Y., S.-L. Chung, B.-M. Jahn, and G. Wu, 2001: Petrologic and geochemical constraints on the petrogenesis of Permian-Triassic Emeishan flood basalts in southwestern China. Lithos, 58, 145-168, doi: 10.1016/ s0024-4937(01)00055-x. [Link]

Yang, R., W. Xu, and R. Liu, 1997: REE geochemistry of Baima complex in the Panxi rift belt. Acta Mineralogica Sinica, 17, 71-77. (in Chinese)

Zhang, X.-Q., X.-Y. Song, L.-M. Chen, W. Xie, S.-Y. Yu, W.-Q. Zheng, Y.-F. Deng, J.-F. Zhang, and S.-G. Gui, 2012: Fractional crystallization and the formation of thick Fe-Ti-V oxide layers in the Baima layered intrusion, SW China. Ore Geol. Rev., 49, 96-108, doi: 10.1016/j.oregeorev.2012.09.003. [Link]

Zhang, Z., J. Mao, A. D. Saunders, Y. Ai, Y. Li, and L. Zhao, 2009: Petrogenetic modeling of three maficultramafic layered intrusions in the Emeishan large igneous province, SW China, based on isotopic and bulk chemical constraints. Lithos, 113, 369-392, doi: 10.1016/j.lithos.2009.04.023. [Link]

Zhong, H., X.-H. Zhou, M.-F. Zhou, M. Sun, and B.-G. Liu, 2002: Platinum-group element geochemistry of the Hongge Fe-V-Ti deposit in the Pan-Xi area, southwestern China. Miner. Depos., 37, 226-239, doi: 10.1007/ s00126-001-0220-0. [Link]

Zhong, H., R.-Z. Hu, A. H. Wilson, and W.-G. Zhu, 2005: Review of the link between the Hongge layered intrusion and Emeishan flood basalts, southwest China. Int. Geol. Rev., 47, 971-985, doi: 10.2747/00206814.47.9.971. [Link]

Zhong, H., I. H. Campbell, W.-G. Zhu, C. M. Allen, R.-Z. Hu, L.-W. Xie, and D.-F. He, 2011: Timing and source constraints on the relationship between mafic and felsic intrusions in the Emeishan large igneous province. Geochim. Cosmochim. Acta, 75, 1374-1395, doi: 10.1016/j.gca.2010.12.016. [Link]

Zhou, M.-F., P. T. Robinson, C. M. Lesher, R. R. Keays, C.-J. Zhang, and J. Malpas, 2005: Geochemistry, petrogenesis and metallogenesis of the Panzhihua gabbroic layered intrusion and associated Fe-Ti-V oxide deposits, Sichuan Province, SW China. J. Petrol., 46, 2253-2280, doi: 10.1093/petrology/egi054. [Link]

Zhou, M.-F., N. T. Arndt, J. Malpas, C. Y. Wang, and A. K. Kennedy, 2008: Two magma series and associated ore deposit types in the Permian Emeishan large igneous province, SW China. Lithos, 103, 352-368, doi: 10.1016/j.lithos.2007.10.006. [Link]

Zhou, M.-F., W. T. Chen, C. Y. Wang, S. A. Prevec, P. Liu, and G. H. Howarth, 2013: Two stages of immiscible liquid separation in the formation of Panzhihua-type Fe-Ti-V oxide deposits, SW China. Geosci. Front., 4, 481-502, doi: 10.1016/j.gsf.2013.04.006. [Link] 